\title{
Toplum Çevirmenliği alanında Türkiye'de yapılan bilimsel çalışmalar: analiz ve değerlendirme
}

Filiz ŞAN 1

\section{Seda KOÇLU²}

\begin{abstract}
APA: Şan, F.; Koçlu, S. (2020). Toplum Çevirmenliği alanında Türkiye'de yapılan bilimsel çalışmalar: analiz ve değerlendirme. RumeliDE Dil ve Edebiyat Araştırmaları Dergisi, (19), 780802. DOI: $10.29000 /$ rumelide. 752813 .
\end{abstract}

\section{$\ddot{O} \mathbf{z}$}

Toplum Çevirmenliği çeviribilim alanında son zamanlarda sıkça gündeme gelen konulardan birisidir. Sahada toplum çevirmenlerine duyulan ihtiyacın artmasıyla, bilimsel araştırmalarda da bu konu farklı açlardan ele alınmaktadır. Bilimsel araştırmaların temel amaç ve çıktılarından birisinin bilime ve söz konusu alana katkı sağlamak olduğu düşüncesiyle hareket edildiğinde, konuyla ilgili yapılmış olan önceki çalışmaların bilinmesinin gerekliliği de ortaya çıkmaktadır. Buna göre araştırma yapılacak konuda ne zaman, hangi yöntemle, ne tür araştırmalar yapılmış ve nasıl sonuçlara varılmış olduğunu bilmek önemlidir. Literatür taraması olarak adlandırılan bu ön çalışma, alana hakimiyet kazandırırken, aynı zamanda yapılacak olan yeni araştırmanın özgünlüğünü de açıklamayı mümkün kılmaktadır. Bundan hareketle bir alanda var olan çalışmalara hakimiyet, aynı alanda yapılacak bilimsel bir araştırmanın ön koşulu olarak görülebilir. Alana hakimiyetin kazanılmasında ise bibliyografyaların önemi oldukça fazladır, çünkü bibliyografyalar bir alanda yapılmış çalışmaların tamamını kayıt altında tutmaktadır. Söz konusu anlayış, bu çalışmanın hareket noktasını oluşturmaktadır. Bu çalışmanın amacı toplum çevirmenliğ alanında gerçekleştirilmiş bilimsel çalışmalara bir üst bakış sunarak, bu sayede başka araştırmalara zemin hazırlamaktır. Söz konusu amaç doğrultusunda toplum çevirmenliği konusundaki bakış açısı aktarılacak ve özellikle yerel koşullardan etkilenmesi nedeniyle toplum çevirmenliği konusunda Türkiye'de ne zaman, nasıl, hangi konularda bilimsel yayın yapıldığı sorularının yanıtı aranacaktır. Kaynakça tarama yöntemiyle tespit edilen yayınlardan hareketle, Toplum Çevirmenliği Bibliyografyası oluşturulacak, toplum çevirmenliğinin alanları dikkate alınarak sınıflandırılacak ve çeşitli parametreler çerçevesinde irdelenerek, değerlendirilecektir. Bu sayede toplum çevirmenliği araştırmalarının Türkiye'deki durumu konusunda bir üst bakış sunulacaktır.

Anahtar kelimeler: Toplum çevirmenliği, bibliyografya, çeviribilim araştırmaları, toplum çevirmenliği alanları

\section{Scientific studies in community interpreting in Turkey: analysis and evaluation}

\begin{abstract}
Community interpreting is one of the topics frequently studied in translation studies in recent years. Community interpreting has been studied from different perspectives in scientific studies as the need for community interpreting practice has increased in the field. Considering the fact that

1 Dr. Öğr. Üyesi, Sakarya Üniversitesi, Fen Edebiyat Fakültesi, Çeviribilim Bölümü (Sakarya, Türkiye), fsan@sakarya.edu.tr, ORCID ID: 0ooo-0oo3-2158-3818 [Makale kayıt tarihi: 28.01.2020-kabul tarihi: 20.06.2020; DOI: $10.29000 /$ rumelide.752813]

2 Arş. Gör., Sakarya Üniversitesi, Fen Edebiyat Fakültesi, Çeviribilim Bölümü (Sakarya, Türkiye), sedakoclu@sakarya.edu.tr, ORCID ID: oooo-0002-6285-9094.
\end{abstract}




\begin{abstract}
one of the main objectives and outcomes of the scientific studies is to contribute to the science and the study area in question, the importance of analysing the previous studies becomes apparent. It is important to know the previous studies, their subjects, their publication year, their research methods and findings. This preparatory work, known as literature review, makes it possible for researchers to obtain a general view of the study field while at the same time also makes it possible to explain the originality of the study to be conducted. Thus, obtaining a general view of previously conducted studies can be considered as the prerequisite for a scientific study to be conducted in the same scientific area. Bibliographies have great importance in gaining that general view of the scientific field, as they give the record of all the studies conducted in a specific field. Thus, this study originates from this understanding. This study aims to provide an overview of the scientific studies conducted in the community interpreting field, and thus to provide a basis for further studies. The study will explain the perspectives in the community interpreting field and will analyze the studies on community interpreting conducted in Turkey, affected by the local conditions, in terms of their publication dates and their topics. A community interpreting bibliography will be created based on the studies found with the literature review method. The studies will be classified in view of the subfields of community interpreting, and they will be analyzed and assessed within the framework of various parameters. Thus an overview of community interpreting studies in Turkey will be presented.
\end{abstract}

Keywords: Community interpreting, bibliography, translation studies, sub-fields of community interpreting

\title{
o. Giriş
}

Türkiye'de Çeviribilimin gelişim süreci incelendiğinde özellikle çeviri eğitimi veren bölümlerin kurulmasıyla bilimsel gelişimin hızlandığı söylenebilir. Akademik çeviri eğitimi veren bölümlerde çevirmen adaylarının yetiştirilmesi, bunun da ötesinde bilimsel bir kürsü olarak çeviribilimin yer edinmesi, bilimsel çalışmaların çeşitlenmesini de sağlamıştır denilebilir. Öte yandan toplumsal, kültürel, ekonomik, siyasi, ticari, teknolojik vb. her türlü gelişme hem çevirinin sektör/alan yelpazesine yansımakta hem de çevirideki araç ve yardımcı araçların gelişmesi nedeniyle çevirmenin çeviri sürecine etki etmektedir. Bu yönüyle çeviribilim, sahayı, sektörü, yani uygulama alanını dikkate alan ve uygulamadaki gelişmelerden beslenen bir bilim dalıdır. Bundan hareketle çevirinin bu özelliği nedeniyle çeviri konusunda gerçekleştirilen Çeviribilimsel araştırmalardaki yönelime etki etmesi bakımından, dinamik bir yapıya sahip olduğunu söylemek yanlış olmayacaktır.

Bu yönde bir etki ve yönelim Toplum Çevirmenliği örneğinde görülmektedir. Siyasi ve toplumsal olayların toplum çevirmenliğe olan ihtiyacı ortaya çıkarması bakımından, bu alanda yapılan araştırmaların artmasına etki ettiği söylenebilir. Uygulama bakımından en eski çeviri alanlarından bir tanesi olarak görülse de toplum çevirmenliği, özellikle 20. yüzyılın sonlarında bilimsel araştırmalara konu olmaktadır. Türkiye'de toplum çevirmenliği araştırmalarında 2011 yllında savaş nedeniyle Türkiye'ye gelen ve geçici koruma altında olan kişiler nedeniyle bir artış olduğu gözlemlenmektedir. Bu bağlamda toplumsal olayların bilimsel çalışmalara etki ettiğine de bir örnek teşkil etmektedir. Bu noktada bilimsel çalışmaların uygulama alanına yansıması da dikkate alındığında, tek taraflı bir etkinin ötesinde, etkileşimsel bir ilişkiden söz etmek daha doğru olacaktır. Buna göre bilimsel araştırmalar bir alanın gelişimine katkı sağlaması ve uygulama alanına yansıması bakımından önemlidir. 
Bilimsel araştırmaların amacı bilimsel alanda var olan bilgileri irdelemek, geliştirmek ve/veya yeni bilgi katarak bilimin ilerlemesine katkı sağlamaktır. Bu amaç doğrultusunda yapılacak olan çalışmalarda öncelikle literatür taraması gerçekleştirilmektedir. Literatür taraması araştırması bilimsel çalışmaların en önemli aşamalarından ve parçalarından bir tanesidir. Bunun sebebi ise, literatür taraması/araştırmasının belirli bir alanda yapılmış olan çalışmalara dair bilgi vermesi, mevcut durumu ortaya koymasıdır. Araştırma sonucu ulaşılan bilgiler, o güne kadar gerçekleştirilen çalışmaları ortaya koyarken, öte yandan yeni yapılacak olan çalışmanın gerekliliğini de açıklamayı mümkün kılmaktadır. Özgünlüğü ortaya koyacak olan, o konuda yapılmış çalışmaların irdelenerek, boşluğun belirlenmesidir. Bu sayede yeni çalışmanın sağlayacağı katkı da belirginleşecektir. Başka ifadeyle literatür taraması bir alanda yapılmış araştırmaları ortaya koyarken, aynı zaman eksik kalan kısımları, boşlukları açıklamayı da olanaklı kılmaktadır. Mevcut araştırmalardan farklı olarak ne yapılacağını ortaya koymak için literatür araştırması gereklidir. Bu araştırmalarda bibliyografya çalışmalarının katkısı ve önemi dikkat çekmektedir. Çünkü bibliyografyalar, bir alanda ya da konudaki çalışmaların kayıt altına alınmış halidir.

\title{
1. Bibliyografyaların tanımı ve önemi
}

Bibliyografyanın etimolojik anlamı 'biblion' = kitap ve 'grabhein'= yazmak kelimelerine dayanmaktadır ve kitap başlıklarının kaydı gibi bir amaç taşımaktadır. Tarihsel gelişimi incelendiğinde bibliyografyanın XV. yüzyılında başladığı görülmektedir ve matbaacılığın kurulup yayılmasıyla birlikte, bibliyografyaların oluşturulması konusunda ilerleme görülmüştür. O yıllarda "bu işi, zamanın bütün bilimlerini devirmiş, bütün kitaplarını yutmuş olan bilginler yapardı. O çağların dini, siyasi, felsefi, ilmi düşünüş ve anlayışının birer tanığı olarak görülen eserleri, bu işin teknik kurallarının, hatta pratik olma kaygılarının örnekleridir. Herhangi bir bilim dalında usta olan adamlar, konuları ya da dil üslupları itibariyle değerli 'kitap hazineleri' veya 'kültür aynaları' bırakmışlardır” (Acaroğlu, 1961, s.135).

Bibliyografyanın ilk resmi tanımı, "tanım (tasvir) ve sınıflama (tasnif) bakımından kitap bilgisi" şeklinde, D. Grand tarafından 1885 yllında yapılmıştır. Grand tanımında, bibliyografya tarihinden, bibliyografya sistemlerinden, kataloglama kurallarından ve repertuvarlardan söz eder. Tarihsel süreçte bu tanım ve içerik daha geniş bir anlam kazanmıştır ve bibliyografya genel anlamda basılmış veya çoğaltılmış metinlerin bilgisi olarak tanımlanmaktadır. "Fikir işlerini kolaylaştırmak için servisler kurmak veya repertuvarlar hazırlamak amacıyla bu dokümanların araştırılması, kaydı, tanımı ve tertibi üzerine kuruludur” (Acaroğlu, 1961, s.137-138). Bu işlemler aynı zamanda bibliyografya oluşturmanın metodunu da ortaya koymaktadır. Yazısında bibliyografyaların tarihsel gelişimini aktaran Türker Acaroğlu, bu işlemleri şu şekilde açıllamaktadır:

\begin{abstract}
"Araștırma tesadüfe bırakılmaz, belli bir metoda uyularak yapılır. Kayıt, zamanımızda her ülkede derli - toplu halde bulunan değişmez kurallara göre, basma metinleri işaret etmekten ibarettir. Tanım, daha ileri giderek, metinleri dıştan veya içten tanıtır. Dış (maddi) tanım kitaba yapılır, makaleye olmaz. Bu iş kitabın eskiliğine veya kalitesine göre, bibliyografyacının güttüğü bilim veya ticaret amacına göre, az-çok değişir. İç tanım metne uygulanır. Özet, analiz ve tenkidli yoruma dayanır. Yazarın amacını, eserinin muhteviyatını, önem ve değerini belirtir. Metinleri yerleştirme sırası demek olan tertibat çok değişiktir. Künye özelliklerine göre olursa: Yazar adlarına, eser başlıklarına, basım yerlerine, yayım tarihlerine göre yapılır veya metinlerin söz açtıkları konulara göre olur. Konuların incelenmesi, belirli bir çerçeveye sı̆̆dırılması istenince, akla uygun bir "sınıflandırma sistemi'nin kabulü gerekir. Orada her konu kendine uygun yeri bulabilmelidir" (Acaroğlu, 1961, s.138).
\end{abstract}


Acaroğlu tarafından yapılan bu tanım bibliyografyaların oluşturulma işlemlerine ışık tutsa da günümüz açısından değerlendirildiğinde kısıtlı kalmaktadır. Çünkü çağımızdaki teknolojik gelişmeler sayesinde farklılaşan bilgi ve belge yönetimi, özellikle bibliyografya gibi kayıtların oluşturulmasında sunduğu araçlar ve bibliyografyalara malzeme olan dijital kaynaklar açısından hem farklılıklar getirmekte hem de önemli imkanlar sunmaktadır. Ancak yine de bibliyografya oluşturulması konusunda çerçevesi belirli bir yöntem önermektedir. Araçlar, kaynaklar veya tanımlar farklılaşsa da, bibliyografyalar her daim büyük bir öneme sahip olmuştur. Bunun izlerini Türkiye'de de sürmek mümkündür.

Tarih boyunca kitap ve kütüphanelere önem verilmiştir. Bu noktada özellikle Katıp Çelebiden (16081657) söz etmek gerekir. "Keşf-üz-zünun an esami-il-kütüp velfünun" onun en önemli eseri olup, batı dillerine de çevrilmiştir. Arapça yazılmış bu eser, daha sonra Milli Eğitim Bakanlığı tarafından yeni harflerle basılmıştır. Türkiye'de 1934 yılında 2527 sayılı Basma Yazı ve Resimleri Derleme Kanununun çıkmasıyla "Türkiye Bibliyografyası" bülteni yayınlanmaya başlamıştır. 1955 yılında da devletçe Ankara Milli Kütüphanesinde kurulan Bibliyografya Enstitüsü Türkiye Makaleler Bibliyografyasını hazırlamaya başlar (bkz. Acaroğlu, 1961, s.139).

Milli Kütüphanenin kuruluş amaçları arasında araştırmacılara çalışmalarında kolaylık sağlamak, araştırma konuları ile ilgili güncel bilgiye ulaşmalarında yardımcı olmak amacıyla çeşitli bibliyografyalar hazırlamak vardır. Bu bibliyografyaların bir kısmı periyodik olarak, bir kısmı ise bir defaya mahsus, talep ve gereksinimlere cevap vermek üzere hazırlanmaktadır. Söz konusu amaçtan hareketle, Milli Kütüphane tarafından çok çeşitli genel ve özel konulu bibliyografyalar yayınlanmaktadır: Türkiye Bibliyografyası, Türkiye Makaleler Bibliyografyası, Cumhuriyet Dönemi Makaleler Bibliyografyası gibi. Ayrıca "Ölümünün 50. Yıldönümü Münasebetiyle Ömer Seyfeddin” ve 1992 yılında yayınlanan "Yunus Emre Bibliyografyaları" gibi Kişi Bibliyografyaları, "Türkçe-İngilizce yayınlanan Basın Bibliyografyası" ve "Türkçe-Arapça hazırlanan GAP Bibliyografyası: Kitap-MakaleHaber” gibi özel konulu bibliyografyalar vardır. Bunlarla birlikte Milli Kütüphane tarafından çeşitli kataloglar da yayınlanmaktadır. Hem genel hem de özel konulu bibliyografyaların varlığı bir ülkenin fikir, sanat, her türlü eserlerini kayıt altına alması bakımından önemli bir yere sahiptir. 3

Çeviri ve Çeviribilim alanında da bibliyografya ve benzeri çalışmalar yer bulmakta ve çalışmaları somutlaştırarak ortaya koyması bakımından alana katkı sağlamaktadır. Hasan Anamur'un "Başlangıçtan bugüne Fransızcadan Türkçeye yapılmış Çeviriler ile: Fransız Düşünürler, Yazarlar, Sanatçllar Üzerine Türkçe Yayınları İçeren bir Kaynakça Denemesi” (2013), Betül Parlak’ın "Bir Çeviri Eserler Bibliyografyası Işı̆̆ında Türkçede İtalyan Kültürü” (2011), Belgin Kader'in "İtalyancadan Türkçeye Çevrilen Eserler Bibliyografyası 1839-2011" (2011), Emine Bogenç Demirel'in "Yazın Alanında Fransızca'dan Türkçe'ye Çevrilmiş Eserler Üzerine Bir Bibliyografya Çalışması” (2003) gibi çevrilmiş eserleri ortaya koyan çalışmalar vardır. Öte yandan çeviribilimsel yayınlara bir üst bakış sunmayı amaçlayan, sınırı ve kısıtı belirlenmiş araştırmalar da yapılmaktadır. Muhammed Zahit Can, Halil İbrahim Balkul, Ahmet Gümüş, Onur Çalık tarafından gerçekleştirilen, "Türkiye’deki Akademik Çeviri Camiasının Makale Düzeyindeki Çalışmalarının Yayın Mecrasının Araştırılması Ve Değerlendirilmesi” (2018), Halil İbrahim Balkul ve Hüseyin Ersoy tarafından kaleme alınan "Çeviribilim Alanındaki Lisansüstü Tezler Üzerine Betimleyici Bir Çalışma” (2016) başlıklı çalışma, Filiz Şan ve Seda Koçlu'nun “Toplum Çevirmenliği Odağında Türkiye'de Yapılan Lisansüstü Tezlere Betimleyici Bir Üst Bakış” (2019) başlıklı yazısı bibliyografya mantığında gerçekleştirilen araştırmalara

3 Milli Kütüphane, http://www.mkutup.gov.tr/tr/Sayfalar/Hizmetlerimiz/Yayinlarimiz.aspx

Adres

Kırklareli Üniversitesi, Fen Edebiyat Fakültesi, Türk Dili ve Edebiyatı Bölümü, Kayalı Kampüsü-Kırklareli/TÜRKIYYE e-posta: editor@rumelide.com
Adress

Kirklareli University, Faculty of Arts and Sciences, Department of Turkish Language and Literature, Kayalı Campus-Kırklareli/TURKEY e-mail: editor@rumelide.com 
örnek olarak gösterilebilir. Bir alanda yapılmış araştırmaları ortaya koymayı amaçlayan bu tür bibliyografya çalışmalarının yeri ve önemi, bilimsel araştırmaların gerekliliği olan literatür taraması düşünüldüğünde ortaya çlkmaktadır.

$\mathrm{Bu}$ çalışmanın hareket noktasını da, bu konudaki farkındalık oluşturmaktadır. Yapılacak başka araştırmalara zemin hazırlamayı amaçlayan bu çalışmada, Toplum Çevirmenliği konusunda yapılan bilimsel araştırmalar odağa alınarak, üst bakış sunulacaktır. Söz konusu amaç doğrultusunda Toplum Çevirmenliği konusundaki bakış açısı aktarılacak ve özellikle yerel koşullardan etkilenmesi nedeniyle Türkiye'deki araştırmalar dikkate alınacaktır. Bu bağlamda öncelikle Toplum çevirmenliğinin Dünya'daki ve Türkiye'deki durumu ortaya koyulacaktır.

\section{Toplum çevirmenliği tanımı ve uygulamaları}

Toplum çevirmenliği dendiğinde akla gelen ilk isimlerden birisi olan Pöchhacker toplum çevirmenliğinin tanımını şu şekilde yapmaktadır: "toplum çevirmenliği, kamu hizmeti sağlayanlar ile bu hizmetten faydalanan bireysel müşterilerin aynı dili konuşmadığı bir toplumda kurumsal ortamlarda gerçekleşen sözlü çeviri türü”. (Pöchhacker, 1999, s.126) Pöchhacker aynı zamanda bu kurumsal alanları [....full and equal Access to legal, health, education, goverment and socail services ] (Pöchhacker, 2000, s. 37, Akt. Slapp Ashley Mar, 2004, s. 12) şeklinde belirlemiştir.

Ayrıca toplum çevirmenliğinin bir kurumsal/kamusal hizmet olduğu tanımından hareketle, bunun zaten İnsan Hakları Evrensel Beyannamesi 21. madde ve 2. Flkrasında, "her şahıs memleketin kamu hizmetlerine eşitlikle girme hakkını haizdir4" şeklinde tasdiklendiği ve toplum çevirmenliğine ihtiyacın vurgulandığı görülmektedir. İnsan Hakları Evrensel Beyannamesinde de iletişim hizmetine erişimin bireyin hakkı olduğuna dair bilgilendirmenin yapıldığı görülmekle birlikte, özellikle göçmen nüfusun fazla olduğu ülkelerde bu iletişim sorununu gidermek adına, toplum çevirmenleri ile çalışılmakta ve uygulama alanında ciddi çalışmalar yürütülmektedir. Bazı uygulamalar ülkede ülkeye farklılık göstermektedir. Bunun sebebi ise her ülkenin kendi ihtiyaçlarını belirlemiş olması ve buna istinaden uygulamalar geliştirmiş olmasıdır.

Örnek bir uygulama göçmen nüfusunun yoğun olduğu ve 224 farklı dil ve sayısız lehçe kullanılan ABD, California'da vardır. Buradaki mahkemelerde gün içerisinde ortalama 80 farklı dilde davalar gerçekleşmektedir. Bu mahkemelerde 2 tür çevirmen vardır. Birisi eğitim almış olması zorunlu olan çevirmenlerdir. Bu çevirmenler devlet tarafından belirlenen belli dillere (daha çok ihtiyaç duyulan diller) yönelik çeviriler gerçekleştirirler. Diğerleri ise devlet tarafından belirlenen diller arasında yer almayan, fakat kullanılan diğer dillerde çevirmenlik yapacak kişilerdir. Çeviri yapacak kişiler tescilli çevirmenler olarak tanımlanmaktadır ve çevirmenlik yapabilmeleri için mahkeme tarafında yapılan yazılı ve sözlü sınavdan başarılı olmaları gerekmektedir (Doğan, 2004, s. 6).

ABD'de sadece mahkeme çevirmenliği ile sınırlı olmayacak şekilde, 13166 sayılı ve başkan Clinton tarafından 2000 yılında imzalanan emir doğrultusunda; federal fon sağlanan tüm kurumların aldıkları fonların iptal edilmemesi adına, İngilizceye tam olarak hakim olmayan müşterilerinin dil ihtiyaçlarını karşılamayı gerekli kılmıştır (Mikkelson, 2014, s. 10). Dolayısıyla toplum çevirmenliği yapacak personellerin istihdamı sağlanmıştır. Beyannamenin Türkçesi için erişim adresi:
http://www.unicef.org.tr/files/bilgimerkezi/doc/insan\%2ohaklari\%2oevrensel\%2obeyannemesi.pdf 
İskoçya'da ise İskoç polislerine çevirmenler ile nasıl çalışılması gerektiği ile ilgili eğitimler verilmiştir. Eğitim çıktılarını edinmek adına polislere anket uygulanmış ve anket sonuçları doğrultusunda polislerin çevirmenin rolünü ve çeviri sürecini, öncesinde çevirmene bilgi vermenin önemini kavradıkları, çevirmenin yaşadıkları zorlukları vb. durumları anladıkları bilgisine ulaşılmıştır (Perez ve Wilson, 2004).

Sağlık alanında ise Almanya'nın Hessen şehrinde bulunan Kassel Kliniği tarafından bir toplum çevirmenliği hizmeti sunulmaktadır. Klinik yabancı hastalar için çevirilerin hastanenin yabancı çalışanlar tarafından gerçekleştirildiği 36 dilde 40 amatör çevirmenin bulunduğu bir amatör çevirmenler listesi (Laien-Dolmetscherliste) yayımlamıştır. Hastane yönetimi, çevirilerin hastane çalışanları tarafından yapılmasının olumlu etki yarattığına dikkat çekmektedir, bunun ise hastane çalışanlarının sağlık bilgileri, bakım bilgilerinin ve işleyişle ilgili bilgilerinin olmasından dolayı olduğunu savunmaktadır5.

$\mathrm{Bu}$ uygulamaların ülkeden ülkeye, hatta eyaletten eyalete farklılık gösterdiği açık bir şekilde hem uygulamalarca hem de kaynaklarca görülmektedir. Örneğin yukarıda da belirtildiği gibi California mahkemelerinde daimi olan 2 tür mahkeme çevirmeni varken ülkemizde mahkemelerde daimi çevirmenler yoktur ve türlere özellikle türlere ayrılmamaktadır. Ülkemizde mahkeme çevirmeni/mahkeme çevirmenliği kavramlarının kullanıldığı fakat daha çok 'bilirkişi' kavramının tercih edildiği bilinmektedir. Adalet Bakanlığı yazılı ve sözlü çevirmeni ayırmamakta ve her ikisini de "tercüme bilirkişi” olarak adlandırmaktadır. Aynı zamanda ülkemizde mahkemelerde bilirkişiler hazır halde beklememektedirler. Gerekli durumlarda davalar için yeminli çevirmenler (bilirkişiler) istenmektedir (Doğan, 2015, s. 144). Bu listeler ise şehirlerin Adalet Saraylarına bağlı resmi sitelerinde 'bilirkişi listesi’ adı altında yayımlanmaktadır.

Türkiye'de çalışmaları devam ettirilen ve dünyada tek olma özelliğini taşıyan bir diğer toplum çevirmenliği örneği ise Afette Rehber Çevirmenliktir (ARÇ). Toplum Çevirmenliğinin alt alanlarından biri olan Afet ve Acil Durum Çevirmenliğine örnek olan ARÇ, 1999 yllında gerçekleşen büyük Marmara Depremi sonrasında yurt dışından gelen çeşitli yardım ekiplerinin, sivil toplum kuruluşlarının yaşadıkları iletişim sorununun fark edilmesiyle ortaya çımıştır. Ani ortaya çıkan bu ihtiyaç ve iletişim sorunu, Türkçeyle birlikte söz konusu yabancı dili az çok bilen kişilerin devreye girmesiyle aşılmaya çalışılmıştır. Prof. Dr. Turgay Kurultay ve Prof. Dr. Alev Bulut'un öncülüğünde afet ve acil durumlardaki çevirmenlik ihtiyacı üzerine düşünülmüş ve 2000 yılında çeviri derneği bünyesinde Afette Rehber Çevirmenlik Organizasyonu kurularak, ARÇ eğitimleri verilmeye başlanmıştır ${ }^{6}$ (Kurultay ve Bulut, 2012).

Bunun haricinde Kızlay Toplum Merkezinde görev yapan çevirmenlere toplum çevirmenliği eğitimi vermeyi amaçlayan, 'Kızılay Toplum Merkezleri - Toplum Çevirmeni Eğitim Programı' isimli bir eğitim programı düzenlenmektedir. Bu proje Kızllay ve Çeviri Derneği öncülüğünde, Çeviri Derneği Başkanı Osman Kaya ve Prof. Dr. Alev Bulut, Prof. Dr. Aymil Doğan, Prof. Dr. Mehmet Hakkı Suçin, Dr. Öğr. Üyesi Filiz Şan ve Dr. Rana Kahraman Duru gibi akademisyenler tarafından yürütülmektedir.7

Uygulama ile ilgili ayrıntılı bilgi için erişim adresi: https://www.gesundheit-nordhessen.de/index.php?parent=1152 ARÇ ile ilgili ayrıntılı bilgi için: http://www.ceviridernegi.org/arc.html

Kızılay Toplum Merkezleri -Toplum Çevirmeni Eğitim Programı programının örneği için bkz: https://www.academia.edu/37799893/K\%C4\%B1z\%C4\%B1lay_Toplum_\%C3\%87evirmenli\%C4\%9Fi_E\%C4\%9Fitim_ Projesi_Program\%C4\%B1_Gaziantep_3_4_Kas\%C4\%B1m_2018 
Ülkelerdeki uygulamalarda bu denli farklılıkların olması bilimsel anlamda da farklı görüşlerin ve farklı yönelimde çalışmaların olabileceği anlamına gelebilmektedir. Nitekim toplum çevirmenliğini ele alan bilimsel çalışmaların çeşitli konuları odağa aldığı görülmektedir.

Sonja Pöllabauer 2003 yllında yaptığı çalışmasında Avusturya'daki İltica Dairelerinde yapılan görüşmeler esnasında gerçekleşen çevirileri analiz etmiştir. Pöllabauer çalışmasında çevirmenin bu süreçte 'görünmez' olmadığı sonucuna varmıştır. Bu bilgiden hareketle toplum çevirmeninin aslında görünür olduğu veya diğer çeviri türlerine kıyasla benzer düzeyde görünür olduğu sonucuna varılabilir.

Mikkelson'un (1996) ise toplum çevirmenliğini konferans çevirmenliği ile kıyaslamıştır. Toplum çevirmenliğinde çevirmenin toplumun güçsüz üyelerine hizmet veren kişilere olarak tanımlamaktadır. Çevirmenin ise buradaki vaziyet alışının önemi vurgulanmalıdır. Zira çevirmen her iki tarafa da eşit uzaklıkta kalmalı ve işlevine uygun çeviri gerçekleştirmelidir.

Aktif şekilde sahada toplum çevirmenliği yapan kişilerin çevirmenlik eğitimi almadıklarından dolayı iş alanı ile ilgili herhangi bir profesyonellikten söz etmek mümkün değildir. Çoğunun profesyonel olarak çevirmenlik eğitimi almadığı gerçeğinden hareketle bazı durumlara nasıl yaklaşmaları gerektiğini bilmemektedirler. Çevirmenlik eğitimi almayan ve profesyonel olmayan bu kişilerin gerçekleştirdiği çevirilerde ise çeşitli sorunlar oluşabilmektedir. Bazı ifadeleri kendi kararları ile çevirmeme, kendi fikirlerini çeviriye dahil etme, terminolojik yetersizlikler, dil yetersizliği, kültürel bilgilerin yetersizliği, karşı tarafta yaklaşım şeklini bilmeme vb. sorunlar çevirinin kalitesinde oynamalara sebep olmaktadır. $\mathrm{Bu}$ durumun çözümü ise ancak ve ancak eğitim ile mümkündür (Krş. Koçlu, 2019, s. 177). Bu uygulamaları amatör olarak gerçekleştiren kişilerin de zaman zaman yanlış anlamalara neden olduğu Hamburg Üniversitesi tarafından yapılan bir projede ortaya çımıştır. Projede hastanelerde sağlık çevirmenliği yapan eğitimsiz kişilerin çeviriye müdahaleleri ve değişiklikler yaptığı görülmüştür (Slapp, 2004, s. 56).

Bu yönde sorunlara işaret eden bir başka araştırmacı Jonathan Ross'tur. Ross, 'amatör-gönüllü' olarak adlandırılan ve hastanelerde gerçekleşen uygulamaların, hasta mahremiyetinin engellenmesi, doğru cevap alınmaması, iletişimde aksamalar, hasta memnuniyetinin azalması, doktor memnuniyetinin azalması, zaman kaybı, yanlış anlaşılmalar vb. sorunlara yol açtı̆̆ını ifade etmiştir (2015, s. 76).

Toplum çevirmenine ihtiyaç duyulduğunda, profesyonel bir çevirmenin bulunmaması durumunda iletişim akrabalar, tanıdıklar ve hatta çocuklar tarafından kurulmaktadır. Bu gibi akraba ilişkilerinin olduğu durumlarda çevirmenlik rolü üstlenen kişilerin duruma tarafsız kalmasının zor olacağı vurgulanması gerekenler arasındadır. Bu konuyu ele alan bilimsel çalışmalarda toplum çevirmenliğine dair görünürlük-görünmezlik, güçlü-güçsüz tarafların bir araya gelmesi, profesyonellik, amatör çevirmenlik, göçmen arka planlı kişilerin çeviri gerçekleştirmesi (akraba, tanıdık, çocukları vb.) ve toplum çevirmenliğinin durumsallığı ile ilgili tartışmalar yürütülmektedir.

Şebnem Bahadır çevirmenin rolünü ve uzmanlığını sorgularken daha esnek, devingen ve durumsallığa bağlı olması gerektiği hususunun göz ardı edilmemesi gerektiğinin altını çizmektedir (Akt. Kahraman, 2003, s. 35). Bunun sebebinin ise toplum çevirmenliğinin doğası gereği tek bir ortamda, tek bir konu çerçevesinde, tek bir kitleye yönelik gerçekleşmemesi gösterilebilir.

Bu uygulama ve yaklaşımlardan görüleceği gibi, toplum çevirmenliği özellikle ülkenin dilini bilmeyen kişilerin yoğun bulunduğu ülkelerde önemli bir yere sahiptir. Türkiye için de durum farklı değildir. 
Özellikle son yıllarda Türkiye'de en çok ihtiyaç duyulan çevirmenlik uygulamalarından birisi olduğunu söylemek yanlış olmayacaktır. Uygulamadaki bu yoğunluktan hareketle, bu alanda araştırmalara ihtiyaç olduğunu doğal bir çıkarım olarak ifade etmek olanaklıdır. Bu bağlamda alanda yapılacak araştırmalar için, Türkiye'de toplum çevirmenliği konusunda yapılmış çalışmalarla ilgili bibliyografya oluşturmak ve bunları inceleyerek üst bakış sunmak önemli bir katkı sağlayacaktır.

\section{Araştırmanın konusu ve yöntemi}

Toplum Çevirmenliği konusunda Türkiye'de gerçekleştirilen araştırmalara üst bakış sunmayı amaçlayan bu çalışmada aşağıdaki soruların yanıtı aranacaktır:

- Bibliyografya oluşturulurken yapılacak araştırmada nasıl bir yöntem tercih edilebilir?

- Yayınların yıllara göre dağılımı nasıldır? Hangi yıllarda artış, hangi yıllarda düşüş görülmektedir?

- Hangi yayın türünde yayın yapılmıştır?

- Yayınlar hangi dillerde yapılmıştır?

- Toplum Çevirmenliğinin hangi alt alanında, ne kadar yayın yapılmıştır?

- Araştırmalar Toplum Çevirmenliğinin alt alanlarına göre sınıflandırıldığında nasıl bir tablo ortaya çlkmaktadır?

- Hangi konularda yayın yapılmıştır?

- Konular nasıl işlenmiştir?

- Araştırmalarda ne tür boşluklar ortaya çıkmaktadır?

- Araştırmalar hangi sorunlara odaklanmaktadır?

- Ylllara göre yönelim hangi ölçüde değişkenlik göstermiştir? vb.

Toplum Çevirmenliği konusunda yapılmış tüm yayınları tespit etmek ve sözü edilen soruların yanıtını aramak, geniş bir tarama gerektirmektedir. Akademik dergiler, üniversite yayınları, lisansüstü tezler, alan kitapları, bildiri kitapları, derleme kitaplar.. Yapılmış bilimsel yayınları eksiksiz olarak tespit etmeyi hedeflemek, yayın mecralarının yoğunluğu ve teknolojik imkanlara rağmen ulaşabilirlik dikkate alındığında iddialı görünmektedir. Bu noktada gerçekçi olmak ve sınırları bilimsel bir yöntemle ${ }^{8}$ belirlemek uygun olacaktır. Google, Yandex gibi arama motorları ya da Google Scholar, Academia, Research Gate gibi akademik ve bilimsel yayınlara yer veren platformlar iyi bir tarama seçeneği gibi görünse de, bilginin söz konusu platformlarda paylaşılmış ya da paylaşılmamış olması ile sınırlı kalmaktadır. Ve bu özelliği nedeniyle bilgiye ulaşılabilirlik konusunda yaşanması olası sıkıntılar değerlendirildiğinde, bazı yayınların gözden kaçması ihtimalinin büyük olması bir gerçeklik olarak ortaya çıkmaktadır. Buna göre önemli olan husus, yukarıda ifade edilen kısıtların farkında olarak,

\footnotetext{
8 Bu çalışmada yöntem belirlenirken Şan ve Koçlu’nun 2019 yllında gerçekleștirdiği 'Toplum Çevirmenliği Odağında Türkiye'de Yapılan Lisansüstü Tezlere Betimleyici Bir Üst Bakış’ başlıklı çalışmasından yararlanılmıştır. Söz konusu yöntem çıkış noktası olarak ele alınmış ve çeşitli parametrelerle geliştirilmiştir.
} 
araştırmalarda belirgin sınırlar belirleyebilmek ve ortaya çıkan araştırma sonuçlarını da, söz konusu kısıt ve sınırlar çerçevesinde değerlendirmektir.

$\mathrm{Bu}$ çalışma kapsamında yayınlara ulaşma yöntemi olarak alanlarda yazılan tezler ve bu tezlerin kaynakçalarından yararlanılmıştır. Hareket noktasına karar verilmesinde, lisansüstü çalışmalardaki araştırmaların kapsayıcı olduğu varsayımı belirleyici olmuştur. Lisansüstü tezlerde araştırmacılar, konuları ne kadar spesifik olursa olsun, geniş bir literatür taraması gerçekleştirir. Bu bir zorunluluk olarak görülmektedir. Çünkü bu tarama tezin özgünlüğü ve alana katkısının belirlenebilmesi için önemlidir. Buna göre diğer yayınlara kıyasla lisansüstü tezlerin çok daha kapsayıcı olması beklenmektedir. Bu noktada belirleyici olan bir başka husus, YÖK Tez Merkezinin sunmuş olduğu tarama imkanı olmuştur. Doğru anahtar sözcüklerle, YÖK tezlere eksiksiz ulaşılmasını olanaklı kılmaktadır. Bu nedenle bu çalışma kapsamında öncelikle toplum çevirmenliği ve alanları konusunda yapılan tezler aranmıştır.

Taramada YÖK9 Tez Merkezi’nde anahtar sözcükler girilerek lisansüstü tezler aratılmıştır. ${ }^{10}$ YÖK’ün arama sayfasında 'aranacak alan' sekmesi bulunmaktadır. Bu sekmenin altında 'danışman', 'dizin', 'konu', 'özet', 'tez adı' ve 'yazar' seçenekleri yer almaktadır. Bu çalışma kapsamında gerçekleştirilen taramada bu seçeneklerin 'tümü' işaretlenmiştir. Arama butonunda 'toplum çevirmenliği', 'toplum çevirisi' ve 'toplum çevirmeni' anahtar kelimeleri aratılmıştır. 'Çevir' kelimesine gelebilecek eklerin (ör. toplum çevirisinin, toplum çevirmeninin, toplum çevirmenliğinde vb.) değişmesi ihtimaline karşı ve bu bağlamda kapsayıcı bir tarama olabilmesi adına, 'toplum çevir' anahtar sözcüğü ile de tarama gerçekleştirilmiştir. ${ }^{11}$ Ayrıca toplum çevirmenliğinin alt alanlar ${ }^{12}$ için de anahtar sözcükler belirlenmiştir. Altı alt alanı için 4'er anahtar kelime belirlenerek ilk taramadaki yöntemle site taratılmıştır (ör. sağlık çevirmenliği, sağllk çevirisi, sağllk çevirmeni, sağllk çevir ya da spor çevirmenliği, spor çevirisi, spor çevirmeni, spor çevir gibi). YÖK Tez Merkezi’nde gerçekleştirilen tarama Türkçe, Almanca ve İngilizce olmak üzere üç dilde yapılmıştır. Buna göre YÖK Tez Merkezinde toplam 84 anahtar sözcük aratılmıştır.

Burada yayınları tespit etmek amacıyla belirlenen yöntem dört aşamadan oluşmuştur. Bunlar:

1. Toplum Çevirmenliği konusunda yapılan lisansüstü çalışmaların tespit edilmesi.

2. Tezlerin kaynakçalarının taranarak Toplum Çevirmenliği konusunda Türkiye'de yayınlanan çalışmaların tespit edilmesi.

3. Kaynakçalarda tespit edilen kaynaklara ulaşıp, onların kaynakçalarının taranması.

4. Taramalar sonucunda ortaya çıkan bulguların sunulması ve değerlendirilmesi

Tarama konusunda belirlenen yöntemin aşamaları anlaşılır olması için aşağıdaki şekilde gösterilmiştir.

YÖK Tez Merkezi için bkz.: https://tez.yok.gov.tr/UlusalTezMerkezi/

Tezlerin taranmasında Şan \& Koçlu'nun 2019 yılında yayınlanan ve Toplum Çevirmenliği konusunda yapılan lisansüstü tezleri konu alan çalışmasındaki tarama yönteminden ve verilerinden yararlanılmıştır.

Tarama işlemi en son 17.09.2019 tarihinde gerçekleştirilmiştir.

Burada Koçlu’nun (2019) alan-tür-kitle ilişkisi bağlamında ortaya koyduğu yaklaşımı geliştirilerek benimsenmiştir.

Adres

Kırklareli Üniversitesi, Fen Edebiyat Fakültesi, Türk Dili ve Edebiyatı Bölümü, Kayalı Kampüsü-Kırklareli/TÜRKİYE e-posta: editor@rumelide.com
Adress

Kurklareli University, Faculty of Arts and Sciences, Department of Turkish Language and Literature, Kayalı Campus-Kırklareli/TURKEY e-mail: editor@rumelide.com 


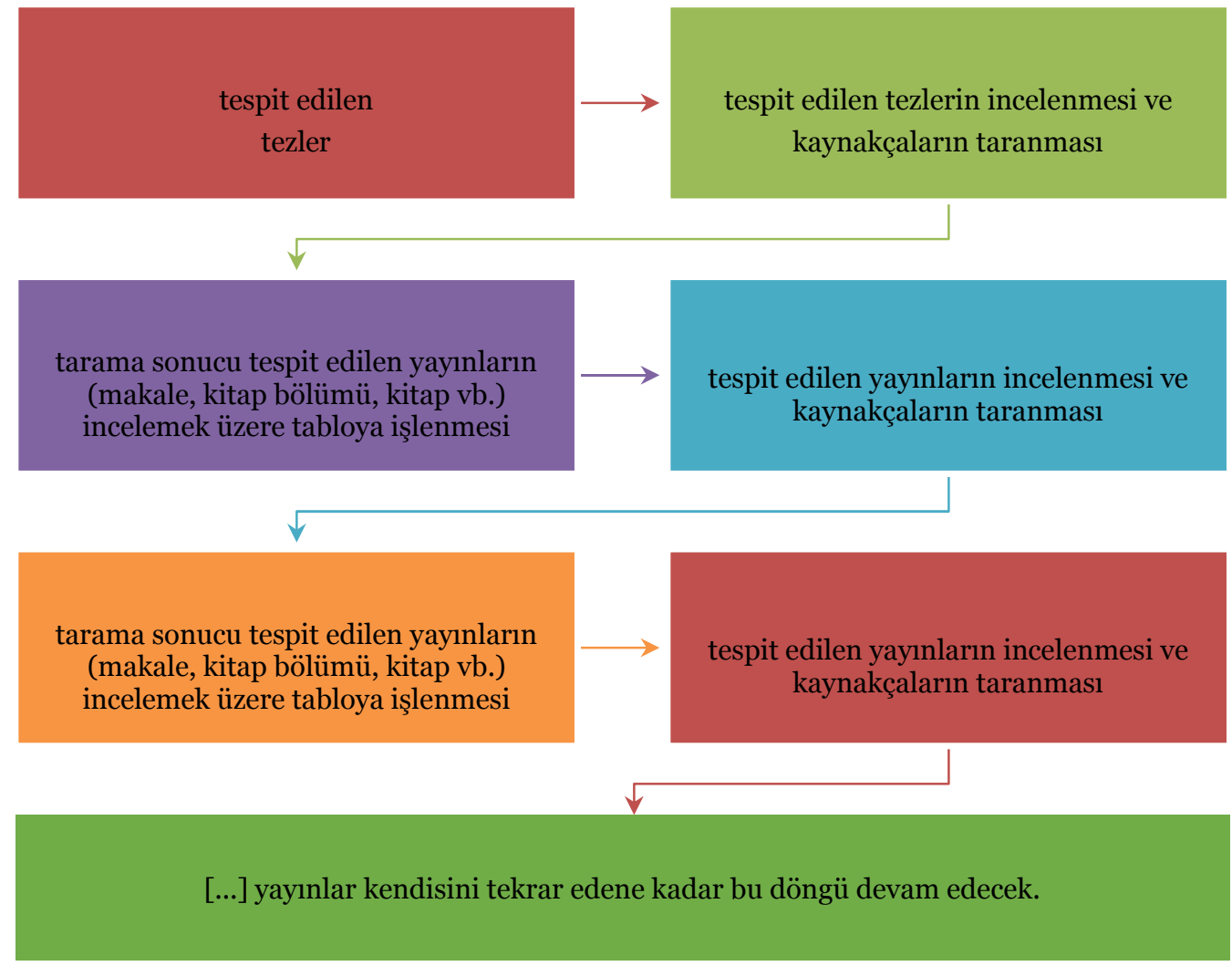

Şema 1: Yöntem Şeması

Şekilden de anlaşılacağı üzere bu tarama, kaynakların kendisini tekrarlamasına değin devam etmiştir. $\mathrm{Bu}$ tarama sonucunda bilimsel kaynak niteliği taşıyan tezlere (tezler bu çalışma kapsamında hem hareket noktası hem de araştırma nesnesi olarak ele alınmıştır), makalelere, kitaplara ve kitap bölümlerine ${ }^{13}$ ulaşılmıştır. Buna göre taramada tespit edilen kaynaklar, çalışma kapsamında belirlenen toplum çevirmenliği alanlarına göre sınıflandırılmıştır. Alanlar kısaca açıklandıktan sonra, araştırma sonucunda ulaşılan yayınlar incelenmiş, kısaca özetlenmiş ve söz konusu alanlar açısından değerlendirilmiştir. Yayınların incelenmesinde ise yayının hangi konuyu ele aldığı, çalışmanın amacının ne olduğu, çalışmayı gerçekleştirirken ne tür bir yöntem benimsendiği ve hangi sonuçların ortaya çıktığı odağa alınmıştır. Ancak bu çalışmanın sınırlılıkları nedeniyle incelemelere burada yer verilmemiştir. Toplum Çevirmenliğinin alt alanlarına göre sınıflandırma yapılarak incelenen yayınlar, söz konusu sınıflandırma dikkate alınarak değerlendirilmiştir. Burada inceleme sonuçlarına ve alt alanlara göre değerlendirmelere yer verilmiştir. Bunların haricinde çalışmaların hangi yıllarda ve hangi dillerde yapıldığına da yer verilmiştir. Bu sayede Türkiye'de (belirlenen kısıtlamalar ve sinırlılıklar çerçevesinde) yayınlanan toplum çevirmenliği konusundaki bilimsel faaliyetlere ve yönelime üst bakış sunulacaktır.

\section{Araştırma sonuçları - bulgular}

Bulgular a) bibliyografya olarak sunulacak, b) sayısal veriler aktarılacak ve c) sinıflandırılarak incelenecek ve değerlendirilecektir.

13 Tam metin yayınlanmış bildiriler de bu çalışma kapsamında kitap bölümü olarak sayılmıştır. 
Yukarıda ifade edilen yöntemle gerçekleştirilen ilk taramada ulaşılan 75 tez içerisinde, farklı anahtar kelimelerle yapılan aramada listelenen aynı başlıklı tezler de yeniden yer almıştır. Aynı olan çalışmaların elenmesiyle toplam 35 tez tespit edilmiştir. Bu lisansüstü tezlerin 2 tanesi alan dış114 (Hemşirelik, Elektrik ve Elektronik Mühendisliği) olup çeviri ve çevirmenliği ele almamaktadır. 2 tanesi ${ }^{15}$ doğrudan konferans çevirmenliğini, 8 tanesi ${ }^{16}$ mahkeme kararları gibi hukuki metinlerin yazılı çevirisini, 1 tanesi ${ }^{17}$ Avrupa Birliği Metinlerinin çevirisini ve 6 tanesi ${ }^{18}$ tıbbi metinlerin yazılı çevirisini odağa almaktadır. Ve bu nedenlerle de bu çalışmanın sınırları dışında kalmıştır. Buna göre 19 tez bu araştırmanın dışında tutulmuştur. Gerçekleştirilen tarama sonucunda toplum çevirmenliği ve alanları konusunda yazılmış 11 yüksek lisans, 5 doktora tezi olmak üzere, toplam 16 tez belirlenmiştir.

Sonraki aşama olan tezlerin kaynakçasının incelenmesiyle devam eden araştırmanın bulguları aşağıdaki şekilde 3 ayrı başlık altında sunulmuştur.

\subsection{Bulgular 1: Türkiye'de toplum çevirmenliği araştırmaları bibliyografyası}

Alimen, N. (2018). Toplum Çevirmenliğine Genel Bir Bakış ve Eğitime Yönelik Yöntem Arayışları. S. Taş içinde, Çeviribilimde Güncel Tartışmalardan Kavramsal Sorgulamalara (s. 249-281). İstanbul: Hiper Yayınları.

Arslan, R. K. (2018). Toplum Çevirmenliği ve Kurumsal Alan İlişkisi . Sakarya Üniversitesi, Sosyal Bilimler Enstitüsü, Çeviribilim Anabilim Dalı, Yayımlanmamış Yüksek Lisans Tezi.

Arslan R. K. ve Durdağı N. (2018). Türkiye'deki Çeviri Eğitimi Veren Yükseköğretim Kurumlarında Toplum Çevirmenliği Alanındaki Derslere Yönelik Bir Araştırma. Sosyal Bilimler Dergisi (23), 368-379.

Balkul, H. İ. (2017). Suriyeli Sı̆̆ınmacılara Sağlanan Yazılı ve Sözlü Çeviri. International Journal of Language Academy (5), 102-112.

Balkul, H. İ. (2018). A Comperative Analysis of Translation/Interpreting Tools Developed For Syrian Refugee Crisis. International Journal of Language Academy(6), 32-44.

Başaran, E. (2013). Sözlü Çevirinin Üvey Evladı: Toplum Çevirmenliği . F. Ö. Şermet içinde, Prof. Dr. Nedret Kuran Burçoğlu'na Armağan: Disiplinlerarası Çalışmalar (s. 435-447). Korpus.

Bulut, A. (2002). The Constraints That Manipulate Interpreting Services at Disasters. International Conference on Translation Studies on New Millenium . içinde Ankara : Bilkent Üniversitesi .

Bulut, A. (2016). Sports Interpreting and Favouritism: Manipulators or Scapegoats? RumeliDE Dil ve Ed ebiyat A raştırmal arı Dergisi, 6 (2), 1-14.

Bulut, A. (2018a). Türkiye'de Futbol Çevirmenliği. İstanbul: Çeviribilim Yayınları.

Bulut, A. (2018b). Türkiye'de Spor Alanında Sözlü Çeviri Uygulama ve Araştırmalar. E. Diriker içinde, Türkiye'de Sözlü Çeviri Eğitim, Uygulama ve Araştırmaları (s. 245-266). Scala Yayıncılık.

Conker, N. (2017). The Professionalization Of Sign Language Interpreting In Turkey: Interpreter Training and Public Interpreting Services . Boğaziçi Üniversitesi, Sosyal Bilimler Enstitüsü, Çeviribilim Anabilim Dalı, Yayımlanmamış Yüksek Lisans Tezi.

Çimen, F. (2009). Yaygın Spor Dallarında Kullamılan İngilizce Terimlerin Benimsenme Süreçleri ve Çeviri İlişkisi. Muğla Üniversitesi, Sosyal Bilimler Enstitüsü, Mütercim Tercümanlık Anabilim Dalı, Yayımlanmamış Yüksek Lisans Tezi.

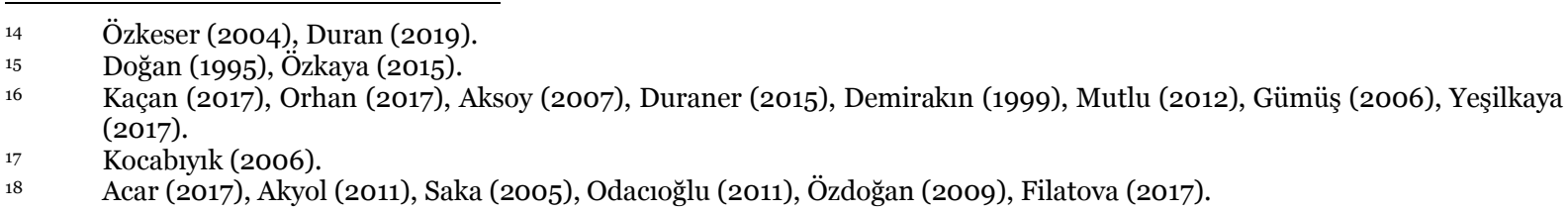


Dinar, G. (2017). Türkiye'de Futbol Alanında Farkh Eyleyenler: Çeviri ve Çevirmenin Rol. Ylldız Teknik Üniversitesi, Sosyal Bilimler Enstitüsü, Batı Dilleri ve Edebiyatları Anabilim Dalı, Mütercim Tercümanlık (Fransızca), Yayımlanmamış Yüksek Lisans Tezi.

Doğan, A. (2004). Mahkeme Çevirmenliği. Hacettepe Üniversitesi Uygulamalı Çeviribilim Dergisi (14), 1-24.

Doğan A. (2006). Afette Rehber Çevirmenlik (ARÇ): Toplum Çevirmenliğinde Yeni Bir Boyut s. 353376 Bizim Büro Basımevi Yayınlar. Ankara.

Doğan, A. (2010). Mahkeme Çevirmenliğinin Dünyadaki Gelişim Aşamaları ve Türkiye'deki Mevcut Durumu - Hacettepe Üniversitesi Çeviribilim ve Uygulamaları Dergisi (20), s. 27-51.

Doğan A. ve Kahraman R. (2011). Emergency and Disaster Interpreting in Turkey: Ten Years of a Unique Endeavour. Hacettepe Üniversitesi Edebiyat Fakültesi Dergisi, 2 (28), 61-77.

Doğan, A. (2012). A Study on the Volunteers of Emergency and Disaster Interpreting Initiative (ARC) in Turkey. Hacettepe Üniversitesi Edebiyat Fakültesi Dergisi, 9(2), 45-58.

Doğan, Ç. (2017). Edirne Özelinde Düzensiz Göçmenlerin Tercümanlk Boyutunda Sorunları Ve Çözümünde Toplum Tercümanhğının Rolü. Sakarya Üniversitesi, Sosyal Bilimler Ensitüsü, Çeviribilim Anabilim Dalı, Yayımlanmamış Doktora Tezi.

Duman, D. (2018). Toplum Çevirmenliğine Yorumbilimsel Bir Yaklaşım: Sağhk Çevirmenliği Ve Öznellik. Yıldız Teknik Üniversitesi, Sosyal Bilimler Enstitüsü, Batı Dilleri ve Edebiyatları Anabilim Dalı, Yayımlanmamış Doktora Tezi.

Duman, D. ve Ataseven F. (2018). Türkiye'de Sağllk Çevirmenliği: Mevzuattan Sahaya. E. Diriker içinde, Türkiye'de Sözlü Çeviri Eğitim, Uygulama ve Araştırmaları (s. 192-214). Scala Yayıncilık.

Eraslan Ş. ve Şener O. (2018). Türkiye'de Hastane Çevirmeninin Rolüne Sosyolojik Bir Yaklaşım. E. Diriker içinde, Türkiye'de Sözlü Çeviri Eğitim, Uygulama ve Araştırmaları (s. 215-244). Scala Yayıncılık.

Ersoy, H. (2018). Göçmen ve Mültecilerin İletişim İhtiyaçlarının Karşlanmasında Çeviri, Kalite ve Empatinin Rolü. International Journal of Language Academy (25), 62-70.

Gürçağlar Ş. ve Diriker E. (2004). Community Interpreting In Turkey. Hacettepe Üniversitesi Çeviribilim ve Uygumaları Dergisi (14), 73-92.

Kahraman, R. (2003). Afette Rehber Çevirmenlik. İstanbul Üniversitesi, Sosyal Bilimler Enstitüsü, Çeviri Anabilim Dalı. Yayınlanmamış Yüksek Lisans Tezi.

Kahraman, R. (2010). Göç ve Çeviri: İltica Başvurularmda Sözlü Çeviri Uygulamaları ve Toplum Çevirmeninin Rolü. İstanbul Üniversitesi, Sosyal Bilimler Enstitüsü, Çeviribilim Anabilim Dalı. Yayınlanmamış Doktora Tezi.

Katar, B. (2019). Dolmetschen im medizinischen Bereich - eine Fallstudie zu Aufgaben- und Rollenprofile von Dolmetscherinnen in der Türkei . Ege Üniversitesi, Sosyal Bilimler Enstitüsü, Mütercim Tercümanlık Anabilim Dalı, Mütercim Tercümanlık (Almanca) Bilim Dalı, Yayımlanmamış Yüksek Lisans Tezi.

Koçlu, S. (2019). Göç ve Çeviri İlişkisi Bağlamında Toplum Çevirmenliğine Üst Bakış: Sakarya Örneği . Sakarya Üniversitesi, Sosyal Bilimler Enstitüsü, Çeviribilim Anabilim Dalı, Yayımlanmamış Yüksek Lisans Tezi.

Kurultay T. ve Bulut A. (2012). Toplum Çevirmenliğine Yeniden Bakışta Afette Rehber Çevirmenlik (ARÇ). İstanbul Üniversitesi Çeviribilim Dergisi (6), 75-102.

Özsöz, B. (2019). Toplum Çevirmenliği Bağlamında Sağllk Turizmindeki Diyalog Çevirilerine Dilbilimsel Ve Çeviribilimsel Yaklaşım. Sakarya Üniversitesi, Sosyal Bilimler Enstitüsü, Çeviribilim Anabilim Dal, Yaymlanmamış Doktora Tezi. 
Öztürk, T. (2015). Küresel Hareketlilik Etkisinde Türkiye'de Sağllk Çevirmenliği Uygulamaları: Çevirmen Görüşlerine Dayah Bir Çalışma. Sakarya Üniversitesi, Sosyal Bilimler Enstitüsü, Çeviribilim Anabilim Dalı, Yayımlanmamış Yüksek Lisans Tezi.

Ross, J. (2018). Toplum Çevirmenliği Eğitimi. E. Diriker içinde, Türkiye’de Sözlü Çeviri Eğitimi, Uygulamaları ve Araştırmaları (s. 283-312).

Şan F. ve Koçlu S. (2018). Sakarya'daki Mültecilerin İletişim Sorunlarının Belirlenmesi ve Toplum Çevirmenliğine Olan İhtiyaç. International Journal of Language Academy, 4 (6), 1-16.

Şener, O. (2017). Healthcare Interpreting in Turkey: Role and Ethics From a Sociological Perspective . Dokuz Eylül Üniversitesi, Sosyal Bilimler Enstitüsü, Mütercim Tercümanlık Anabilim Dalı, Mütercim Tercümanlık (İngilizce) Bilim Dalı, Yayımlanmamış Yüksek Lisans Tezi.

Toker, S. (2019). Evaluation Of Adaptation Training Provided By The Ministry Of Health And The World Health Organization: Patient Guides Within The Context Of Healthcare Interpreting Training In Turkey. Hacettepe Üniversitesi, Sosyal Bilimler Enstitüsü, Mütercim-Tercümanlık Bilim Dalı, MütercimTercümanlık (İngilizce) Ana Bilim Dalı, Yayımlanmamış Yüksek Lisans Tezi.

Turan, D. (2016). Sağ lık Hizmetlerinde Sözlü Çeviri. Ankara: Grafiker Yayınları.

Turan, D. (2018). Sağlık Çevirmenliği: Hekim-Hasta İletişimi ve Hekimin İktidar Pozisyonunun Değerlendirilmesi Üzerine Bir Çalışma. Turkish Studies, 13(22), 751-777.

Uyanık, G. B. (2015). Spor Çevirmenliğinde Durumların ve Görevlerin Tanımlanması. İstanbul Üniversitesi, Sosyal Bilimler Enstitüsü, Çeviribilim Anabilim Dalı, Yayımlanmamış Yüksek Lisans Tezi.

Yücel, B. E. (2018). Mahkeme Çevirmeninin Rolü ve Görünürlüğü. İstanbul Üniversitesi, Sosyal Bilimler Enstitüsü, Çeviribilim Anabilim Dalı, Yayımlanmamış Doktora Tezi.

\subsection{Bulgular 2: sayısal veriler}

Toplum Çevirmenliği ve alanları konusunda Türkiye'de yayınlanan toplam 39 yayına ulaşılmıştır. Yıllara göre yayın sayıları aşağıdaki grafikte gösterilmiştir.

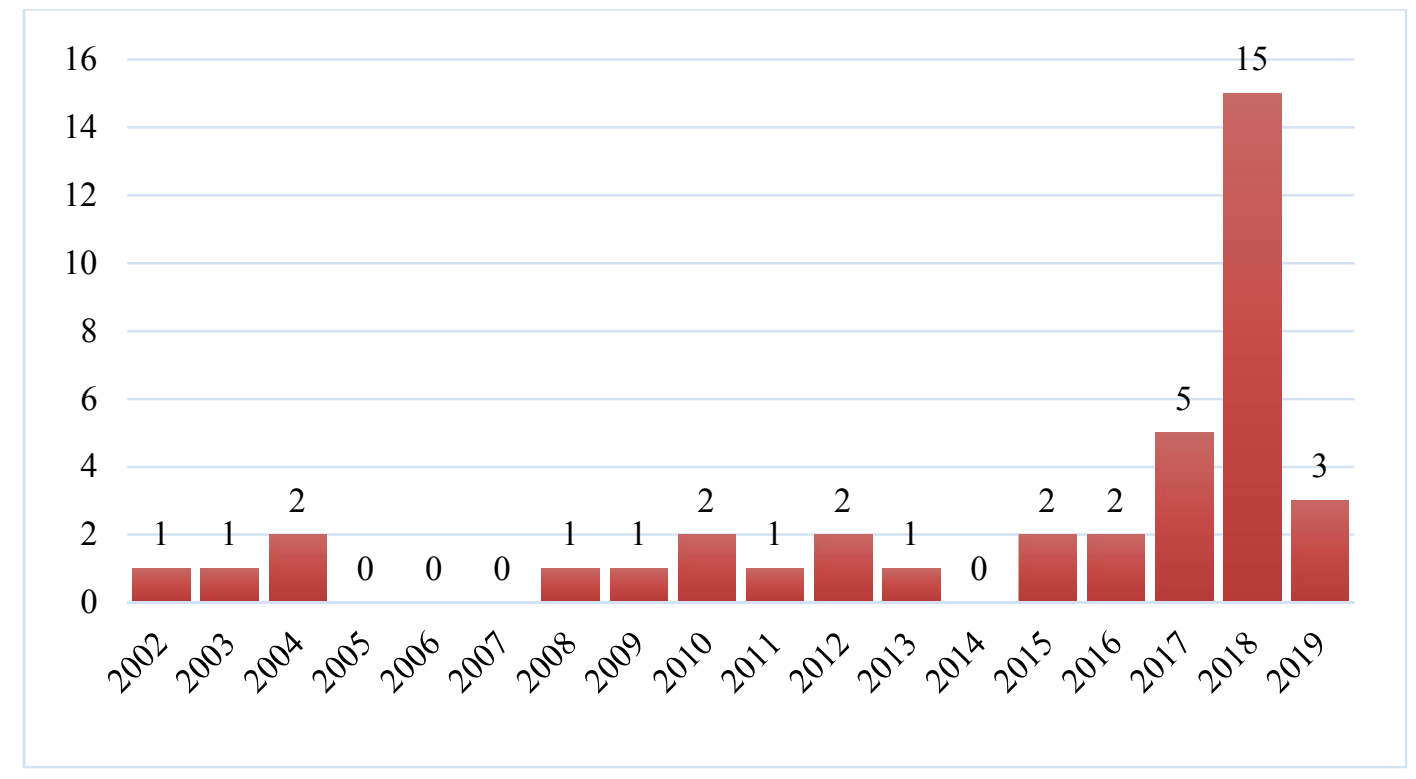

Grafik 1: Türkiye'de Toplum Çevirmenliği Konusunda yayınlanan çalışmaların yıllara göre dağılımı 
Belirlenen kısıtlar çerçevesinde yapılan taramada Toplum Çevirmenliğini/Alanını konu alan ilk çalışmanın 2002 yılında yayınlandığı görülmüştür. O yıldan itibaren 2016 yılına kadar aralıklarla minimum düzeyde (o-2) yayın yapılmıştır. Grafiğe bakıldığında dikkat çeken husus 2017 yılından sonra bu konudaki yayın sayısının ciddi oranda artmış olmasıdır. Buna göre 2002-2019 yıllar arasında yayınlanan araştırmaların \%59'u son üç yılda yapılmıştır. Bu dağılımdan hareketle, toplum çevirmenliğinin son yıllarda büyük ilgi gördüğü açıkça söylenebilir. Bunun önemli nedenlerinden bir tanesi olarak Türkiye'nin son yıllarda aldığı dış göç ve toplum çevirmenliğini de kapsayan meslekleşme ${ }^{19}$ çalışmaları gösterilebilir.

Yukarıda da ifade edildiği gibi taramada yayın dili ve yayın türü de dikkate alınmıştır. Bu parametreler odağa alındığında ortaya çıkan sayılar ve oranlar aşağıdaki gibi grafikleştirilmiştir.

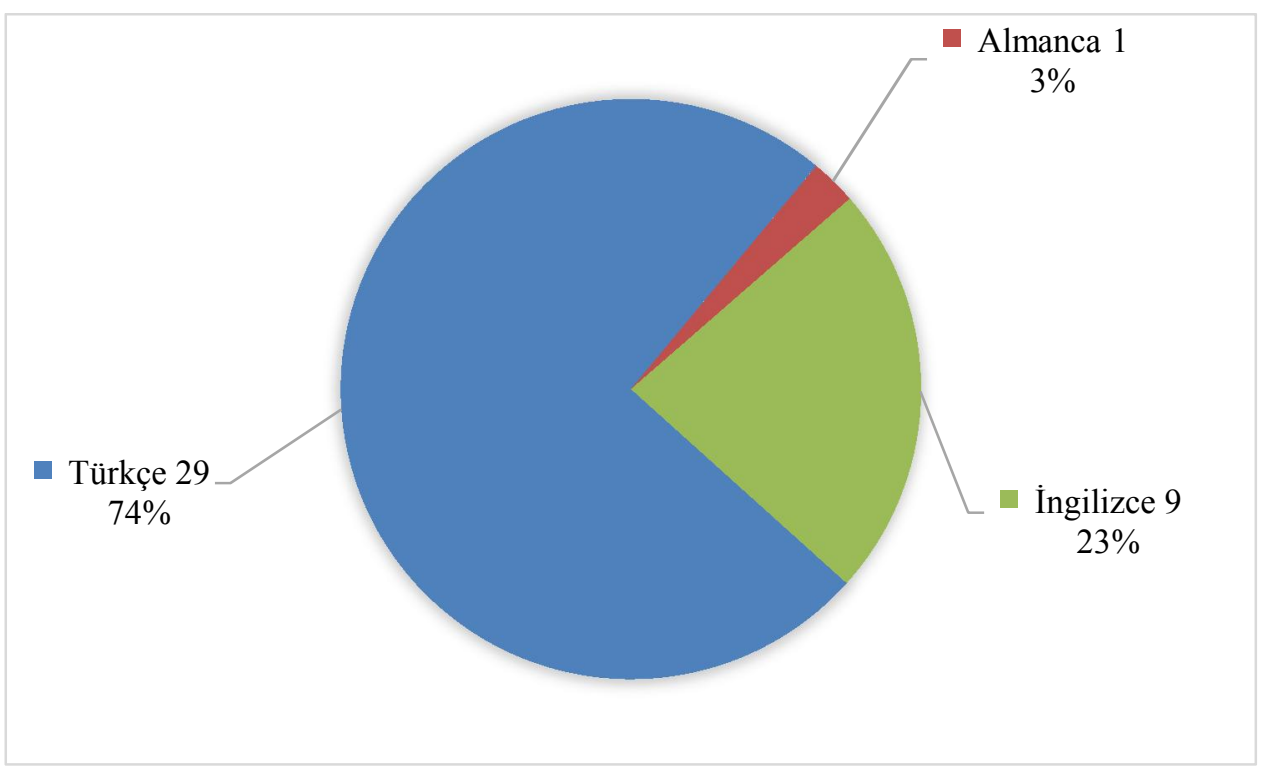

Grafik 2: Türkiye'de Toplum Çevirmenliği Konusunda yayınlanan çalışmaların dillere göre dağılımı

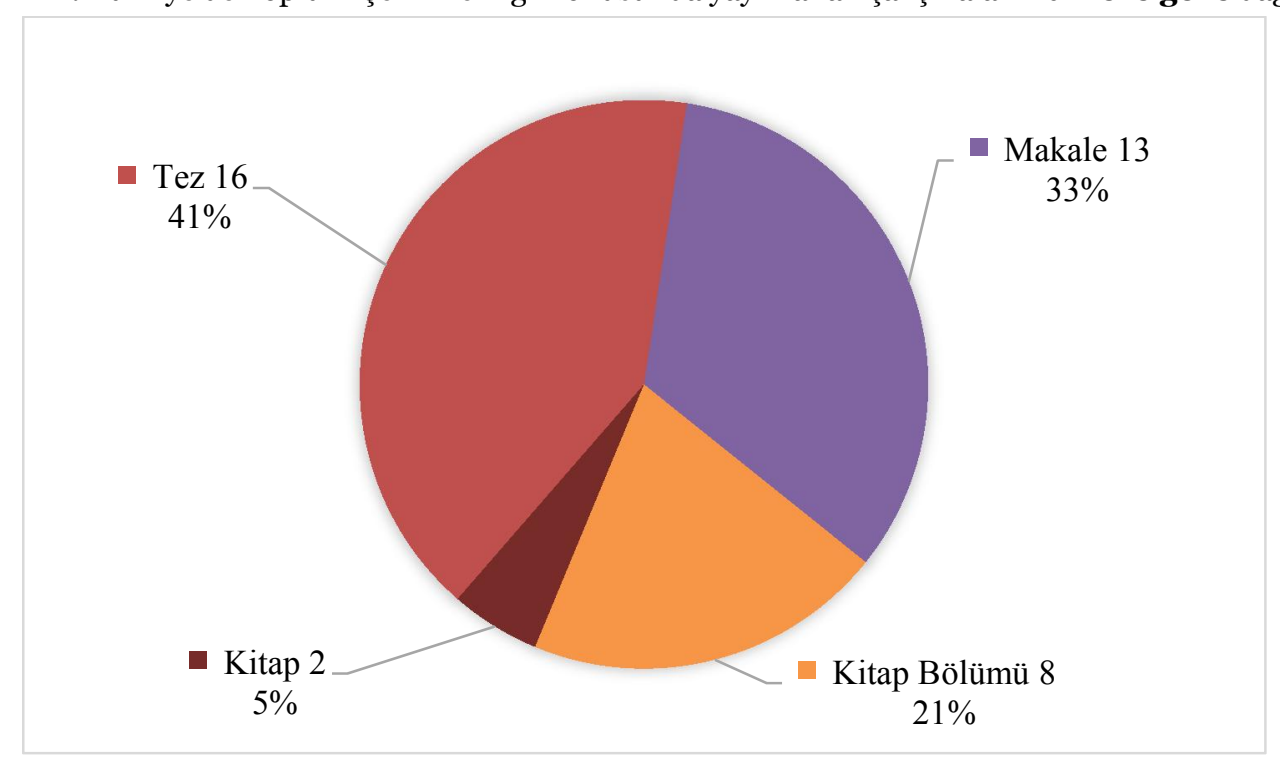

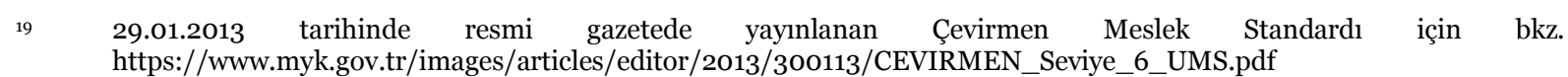


Grafik 3: Türkiye'de Toplum Çevirmenliği Konusunda yayınlanan çalışmaların yayın türüne göre dağılımı

Grafiklerden de görüleceği gibi tarama sonucunda tespit edilen yayınların 29'u Türkçe, 9’u İngilizce ve 1 tanesi de Almanca yayınlanmıştır. Yayın türüne bakıldığında yayınların büyük bir çoğunluğunun, yani \%41'lik kısmının, tezlerden oluşmakta olduğu dikkat çekmektedir. Genel tablo incelendiğinde ilk tezin 2003 yılında yayınlandığı görülmektedir (bkz. Ek1). Tezlerin yıllara göre dağılımı bakımından değerlendirildiğinde, geçmişten günümüze kadarki süreçte her daim toplum çevirmenliğinin lisansüstü çalışmalara konu olduğu söylenebilir. Yayınların \%33’ü makale, \%21’i ise kitap bölümüdür. Bunların ekte verilmiş tablodan yıllara göre dağılımı incelendiğinde kitap bölümüne özellikle son yıllarda ağırlık verildiği görülmektedir. Bunun nedeni olarak, çeviribilim alanında derleme kitap çalışmalarının sayısının artması gösterilebilir. Bu tür yayınlar kitap bölümü çalışmalarına olanak sağlamaktadır. 39 yayının 2 tanesinin kitap olduğu görülmüsştür. Kitapların yayın yılı 2016 ve 2018’tir. Son 3 yılda toplum çevirmenliği konusundaki yayınların büyük oranda arttığı dikkate alınırsa, yönelim bakımından bu konuda yayınlanacak kitapların da artacağı ön görüsünde bulunulabilir.

$\mathrm{Bu}$ çalışmanın ana amaçlarından biri Toplum Çevirmenliği ile ilgili bir bibliyografya sunmanın yanında hangi konular odağında araştırmalar yapıldığını belirlemek olduğu için, bu amaca ulaşmada toplum çevirmenliği alanlarına göre yayın sayıları ve oranlar da önemli yer tutmaktadır.

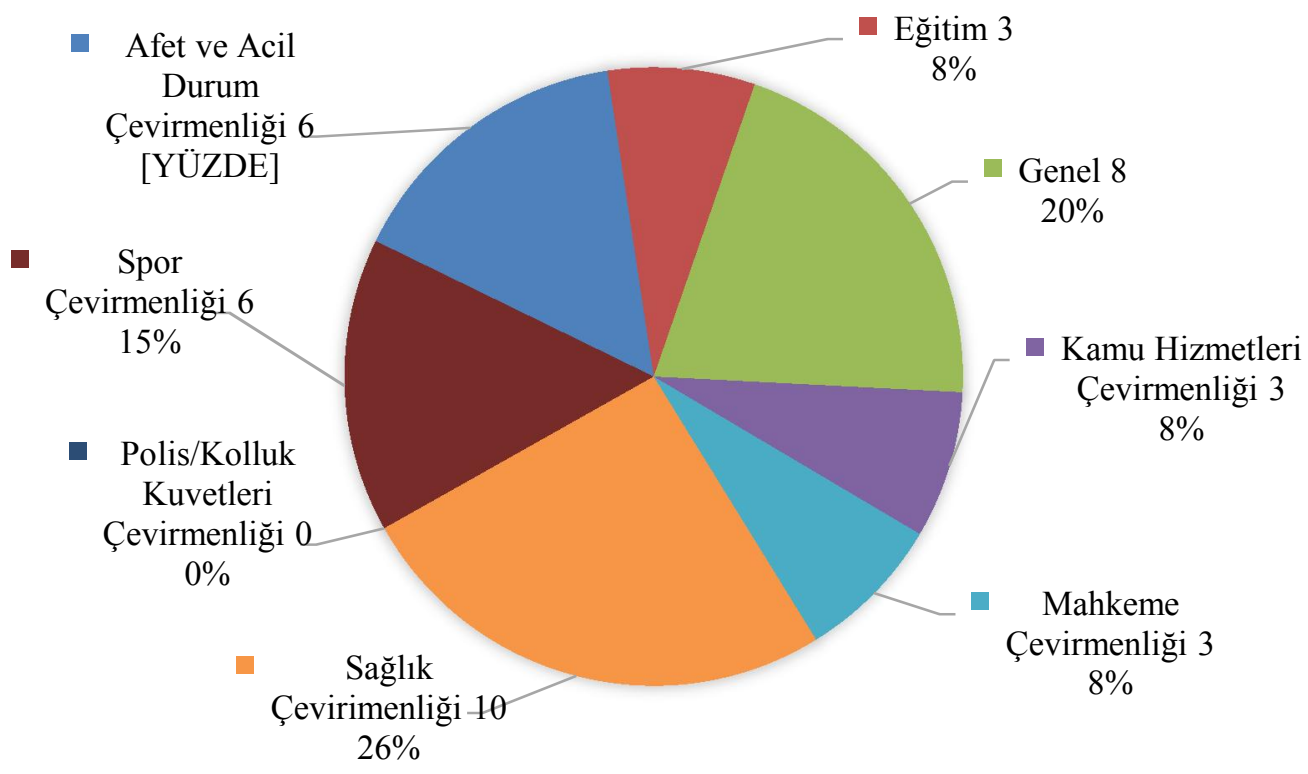

Grafik 4: Türkiye'de Toplum Çevirmenliği Konusunda yayınlanan çalışmaların alanlara göre dağılımı

Grafikteki verilere göre (eğitim ve genel konuları ele alan yayınlar hariç) Türkiye'de Toplum Çevirmenliği konusunda yayınlanan bilimsel çalışmaların sayısına bakıldığında, en çok Sağlık Çevirmenliği alanında, ikinci olarak Afet ve Acil Durum Çevirmenliği ve Spor Çevirmenliği ve sonrasında Mahkeme Çevirmenliği ve Kamu Hizmeti Çevirmenliği konularında yayın yapıldığı görülmektedir. Polis/Kolluk Kuvvetleri Çevirmenliği konusunda ise hiç yayın yapılmadığı dikkat çekmektedir.

Grafiklerden hareketle hangi alanlarda, hangi yllarda, hangi yayın türünde ve hangi dillerde ne kadar yayın yapıldığı görülmüştür. Böylelikle Toplum Çevirmenliği araştırmalarının Türkiye'deki 
görünümüne ve yönelimine üst bakış elde edilmiş olmakla beraber, alanlarda yapılan çalışmaların detayları incelenerek değerlendirilecek ve genel resim ortaya koyulmaya çalışlacaktır.

\subsection{Bulgular 3: Türkiye'de toplum çevirmenliği araştırmalarının alanlara göre sinıflandırılması ve incelenmesi}

Çalışma kapsamında ulaşılan yayınlar özellikle toplum çevirmenliğinin alt alanları dikkate alınarak sınıflandırılmıştır. Ayrıca, Afet ve Acil Durum Çevirmenliği, Kamu Hizmeti Çevirmenliği, Mahkeme Çevirmenliği, Polis/Kolluk Kuvvetleri Çevirmenliği, Sağlık Çevirmenliği, Spor Çevirmenliğine ek olarak, toplum çevirmenliğini belirli bir alanla sınırlı olmaksızın kapsayıcı şekilde ele alan 'Toplum Çevirmenliği Genel' ve eğitim konusuna odaklanan 'Toplum Çevirmenliği Eğitimi' başlıkları da belirlenmiştir. Yayınlar bu başlıklar altında sınıflandırılmıştır. Yayınların her biri konu, amaç, yöntem ve sonuç dikkate alınarak incelenmiştir. Bu kapsamda gerçekleştirilen incelemeler sonucunda alanlara göre ortaya çıkan bulgular ve değerlendirmeleri aşă̆ıda verilmiştir.

\section{a) Afet ve acil durum çevirmenliği ${ }^{20}$}

Afet ve acil durum çevirmenliği, trafik kazaları, doğal afetler gibi durumlarda gerçekleştirilen çeviri eylemi için kullanılan adlandırmadır. Uluslararası yardımlaşmayı gerektiren afetlerdeki çeviri ihtiyacını karşılamak amacıyla oluşturulan Afette Rehber Çevirmenlik organizasyonu buna iyi bir örnektir. ARÇ Türkiye'de toplum çevirmenliğinin alt alanlarından birisidir ve ihtiyaçtan hareketle ortaya çıkmıştır. Yaşanan Marmara Depreminden (1999) sonra uluslararası yardımlaşma kapsamında yurt dışından gelen arama kurtarma ve yardım ekiplerinin iletişim sorunlarını çözmek üzere gerçekleştirilen bir çeviri hizmetidir. O yllarda gelen ekiplerin depremden etkilenen vatandaşlara yardım etmede, ayrıca devlet kurumları ve Türk arama-kurtarma ekipleriyle eşgüdümlü hareket etmede iletişim sorunu yaşadıkları görülmüştür. Çalışmalar neticesinde 2001 yılında ARÇ Çeviri Derneğinin bünyesinde kuruldu.

Yapılan araştırmada Afet ve Acil Durum Çevirmenliği alandaki yayınların tamamının Afette Rehber Çevirmenlik konusunda yapıldığı görülmüştür. Grafikten hareketle bu konuda yapılan araştırmaların azımsanmayacak sayıda olduğu söylenebilir. Buna göre Toplum Çevirmenliğinin alanları arasında sağlık çevirmenliğinden sonra en fazla yayın Afet ve Acil Durumla ilgili yapılmıştır ${ }^{21}$. Bununla birlikte Türkiye'de Toplum Çevirmenliği alanlarını konu alan ilk çalışmaların ARÇ konusunda yapıldığı da vurgulanmalıdır. Söz konusu araştırmalar 2002 ve 2003 yıllarında gerçekleştirilmiştir. Çalışmalar incelendiğinde, bu konuda ağırlıklı olarak tanıtıcı çalışmaların yapıldığı görülmektedir. Afette Rehber Çevirmenlik türünde bir organizasyonun hem Türkiye'de, hem de dünyada örneğinin bulunmaması, bu tür tanıtıcı yayınların gerekliliğini de açıklamaktadır. Yayınlar tanıtıcı olduğu kadar, Afette Rehber Çevirmenlik eğitiminin önemine de vurgu yapmaktadır. Daha yeni yayınlarda özellikle değişen koşulların da dikkate alındığı görülmektedir. Afet gibi önemli bir odağı bulunan Afette Rehber Çevirmenlikle ilgili araştırmalara yurt içinde ve dışında gerçekleşen afetlerde, afet öncesi/sırası/sonrası için koordinasyon ve planlama ile ilgili her türlü değişikliğin ve gelişmenin yön vermesi söz konusudur. Bu bağlamda afet varlığını sürdürdüğü sürece Türkiye’de Toplum

\footnotetext{
20 Bu alanda yapılan yayınlar: Bulut (2002), Kahraman (2003), Doğan (2008), Doğan ve Kahraman (2011), Kurultay ve Bulut (2012), Doğan (2012)

21 Tarama sırasında ARÇ konusunda yapılan (burada yer verilen çalışmaların haricinde) birçok yayına rastlanmıştır, ancak ya tam metni yayınlanmamış sözlü bildiri olması ya da yurt dışında yayınlanması nedeniyle bu çalışmaya dahil edilmemiştir. Söz konusu çalışmalara bazı örnekler; Bulut ve Şan (2019), Bulut ve Kahraman (2003), Doğan (2010a, 2010b).
} 
Çevirmenliği alanlarından biri olan Afet ve Acil Durum Çevirmenliğine örnek olan ARÇ’ın da koşullar çerçevesinde araştırmaları ve eğitim çalışmaları ile gelişeceği kesindir.

\section{b) Kamu hizmeti çevirmenliği ${ }^{22}$}

Kamu hizmeti çevirmenliği Pöchhacker (1999, s. 126) tarafından şu şekilde tanımlanmaktadır: "Kamu hizmeti sağlayıcılarının ve bireysel müşterilerin aynı dili konuşmadığı toplumun kurumsal ortamında gerçekleşen çeviri”. Rillof ve Buysse ise tanımı bir adım öteye taşıyıp daha kapsayıcı bir tanım ile kamu hizmeti çevirmenliğini en geniş anlamla, sosyal hizmet birimlerinde sözlü, yazılı ve işaret dili, sağlık hizmetleri, yargı, polis, eğitim, refah, çocuk ve gençlik bakımı, iltica ve mülteci prosedürleri ve mağdur destek hizmetlerini içerdiği şeklinde tanımlamıştır (2015, s. 191).23

Taramada ulaşılan verilere göre Kamu Hizmeti Çevirmenliğini konu alan çalışmaların az olduğu ve söz konusu 3 çalışmanın de tez olduğu görülmüştür. Toplum Çevirmenliği konusunda yapılan çalışmaların \%8’ini Kamu Hizmeti Çevirmenliği alanı oluşturmaktadır. Bu alandaki ilk tez çalışması 2010 yılında gerçekleştirilmiştir. Yapılan çalışmaların biri işaret dili çevirmenliğini odağa alırken, Rana Kahraman (2010) tarafından hazırlanan diğer çalışma ise mültecilerin iltica sürecini ele almıştır. Bu alanda yapılan son tez çalışmasının ise kamu hizmetleri çevirmenliği alanını daha genel bir yaklaşımla irdelediği görülmüştür. Bu tez çalışmaları, her ne kadar birbirinden farklı odaklar çerçevesinde kamu hizmeti alanında gerçekleşen çeviri faaliyetlerini ele alsalar da, ortak bir soruna işaret etmektedir. Çalışmalarda kurumlardaki eksikliklerin altı çizilirken, uzmanlaşmaya ve profesyonel çevirmenlere olan ihtiyaç vurgulanmaktadır. Kamu Hizmeti Çevirmenliği konusundaki yayınlarla ilgili bulgulardan hareketle kurumlar özelinde detaylı çalışmalar yapılması gerektiği çıkarımında bulunulabilir.

\section{c) Mahkeme çevirmenliği24}

Aymil Doğan (2004, s.2) mahkeme çevirmenliğini "demografik özelliklere sahip ülkelerde, vatandaşların mahkeme ortamındaki iletişim gereksinimini karşılamak üzere, genellikle ikili görüşme esasına dayalı olarak kimi zaman da andaş, ardıl ve fısıldayarak çeviri olarak gerçekleştirilen bir sözlü çevirmenlik türü” olarak tanımlamaktadır.

Toplum Çevirmenliği konusunda yapılan çalışmaların \%8inin Mahkeme Çevirmenliği alanında yapıldığı grafikten görülmektedir. 3 yayın yapılmış olması sayıca az gibi görünse de özellikle hukuk çevirisini konu alan oldukça fazla çalışma olduğu söylenmelidir. Bu çalışma kapsamında belirlenen kısıtlar çerçevesinde özellikle Toplum Çevirmenliğine konu olan, mahkemede gerçekleştirilen çeviri faaliyetleri ile ilgili çalışmalar dikkate alınmıştır. Hukuk çevirisi konusundaki çalışmalar daha çok uzmanlık alan çevirisi olarak değerlendirildiğinden bu çalışmanın dışında tutulmuştur.

Kamu Hizmeti Çevirmenliğinde de olduğu gibi, Mahkeme çevirmenliğini konu alan bilimsel çalışmaların görece azlığı dikkat çekmektedir. Bunun bir nedeni çalışma kapsamında toplum çevirmenliğinin odağa alınmasıyla, bu alandaki araştırmanın mahkeme çevirmenliği ile sınırlı tutulmuş olması olabilir (bkz. yöntem). Yapılan çalışmalar incelendiğinde mahkeme çevirmenliğinin

\footnotetext{
$22 \quad$ Bu alanda yapılan yayınlar: Kahraman (2010), Conker (2017) Arslan (2018)

23 Bu yaklassımda Kamu Hizmeti Cevirmenliği alanının sağllk çevirmenliği, polis merkezi cevirmenliği ve mahkeme çevirmenliği konularını da içine aldığı görülmektedir. Bu araştırmada söz konusu tezler kendi araştırma alanlarını odağa aldığı için ayrı alanlar olarak sınıflandırılmıştır. Buna göre hem genel anlamda kamu hizmeti çevirmenliği alanına kapsayıcı yaklaşım sunan çalışmaların da olması sebebiyle kamu hizmeti çevirmenliği, hem de diğer alanlar ayrı başlıklar altında incelenmiştir.

24 Bu alanda yapılan yayınlar: Doğan (2004), Doğan (2010) Yücel (2018)
} 
farklı açılardan ele alıp çok boyutlu olarak irdelendiği ve veri ve içerik analizi yöntemiyle saha araştırması yapıldı̆̆ı görülmektedir. Bu bağlamda bu çalışmalar üzerinden hem mahkemede mevcut iş potansiyeli belirlenmiş hem de mahkemede görev yapan çevirmenlerin durumu ortaya koyulmuştur.

\section{d) Polis/kolluk kuvvetleri çevirmenliği}

Yapılan taramanın sonucunda ve alanlara göre ortaya çıan dağılım incelendiğinde, Polis/Kolluk Kuvvetleri Çevirmenliği alanında hiç yayının olmadığı görülmüştür. Bu konu odağında yayın yapılmamış olması, bu alanda çeviri çalışmalarının olmadığı anlamına gelmemektedir. Genel anlamda Toplum Çevirmenliği ya da Kamu Hizmetleri Çevirmenliği konusunu ele alan çalışmalarda kısmen konuya değinilmektedir, ancak Polis/Kolluk Kuvvetleri Çevirmenliği odağında yayına rastlanmamıştır. Buna göre bu alt alan özelindeki durum ve sorunları ele alacak çalışmalara ihtiyaç olduğu söylenebilir.

\section{e) Sağlık çevirmenliği25}

Sağlık çevirmenliği hastanelerde, sağlık ocaklarında, trafik kazaları gibi acil durumlarda yabancı hastalar ile hekimler arasında iletişim sağlamak amacıyla gerçekleştirilen bir çeviri türüdür. $\mathrm{Bu}$ çevirmenlik türüne ülkemizde oldukça fazla ihtiyaç duyulmaktadır. Estetik veya saç ekimi vb. muayeneler veya ameliyatlar için ülkemize gelen yabancılara yönelik gerçekleşen çeviriler sağllk çevirmenliği olarak değil, sağlık turizmi olarak değerlendirilmektedir. İki uygulama arasındaki en belirgin fark sağlık turizminde diğerine kıyasla önceden planlanmış bir muayene olması ve genellikle özel hastanelerdeki hizmetleri kapsamasıdır. Buna karşın sağlık çevirmenliğinde ise genelde spontane gelişen ve çevirmenin bulunmadığı sağlık birimlerinde dil bilen kişilerce yapılan çeviriler görülmektedir.

$\mathrm{Bu}$ görüşten hareketle yapılan araştırmada tespit edilen bilimsel çalışmalara bakıldığında, öncelikli olarak dikkat çeken husus, Toplum Çevirmenliğinin alanları arasında en çok bilimsel çalışmanın sağlık çevirmenliği alanında yapıldı̆̆ıdır. Grafiğe göre çalışmaların \%26’sını oluşturmaktadır. Bununla birlikte (bu çalışma kapsamında belirlenen kısıtlar dikkate alınarak gerçekleştirilen taramaya göre) ilk bilimsel çalışmanın 2015 yılında yapılmış olması da göze çarpmaktadır. Yayınlarda tür bakımında öne çıkan çalışmaların lisansüstü tezler olduğu görülmüştür. Bu bağlamda çalışmaların yarısından fazlası tez olmakla birlikte 10 çalışmanın tamamı son 4 yılda yapılmıştır. Çalışmalarda çevirmenin konumu ve rolü, sağllk çevirmenliği alanındaki mevzuat ve mevcut durum tespiti gibi hususlar irdelenmiştir. Bu kapsamda gerçekleştirilen çalışmaların büyük çoğunluğunda anket uygulamaları, mülakat, görüşme ve röportajlarla özellikle saha araştırılmıştır. Son yıllarda bu konunun bilimsel çalışmalarda ele alınmasının önemli nedenlerinden birinin, özellikle Suriye'deki savaş nedeniyle Türkiye'ye gelen ve ülkenin dilini bilmeyen kişilerin yoğunluğu ve en önemli ihtiyaçlarından birinin sağlık hizmeti olduğu söylenebilir.

\section{f) Spor çevirmenliği ${ }^{26}$}

Spor çevirmenliği Uyanık (2015: 22) tarafından şu şekilde tanımlanmıştır: "Spor çevirmenliği, spor kulüplerinde ve spor organizasyonlarında bir takım, antrenör ya da oyuncu için çalışan bir sözlü çevirmen tarafından verilen ardıl çeviri hizmetidir. Bu bağlamda spor çevirmeni, bir spor

\footnotetext{
25 Bu alanda yapılmıs yayınlar: Öztürk (2015), Turan (2016), Şener (2017), Çurum Duman (2018), Çurum Duman ve

26 Ataseven (2018), Turan (2018), Eraslan ve Şener (2018), Katar (2019) Özsöz (2019), Toker (2019)
} 
organizasyonu için ad hoc olarak veyahut bir spor kulübünce kadrolu olarak istihdam edilen sözlü çevirmendir”.

Grafikler incelendiğinde Türkiye'de toplum çevirmenliği konusunda yapılan yayınların \%15’inin spor çevirmenliği konusunda yapıldığı görülmektedir. Spor Türkiye'de her daim gündemde olan konulardan biridir. Buna paralel olarak eskiden beri antrenörlere ya da futbolculara çevirmenlik yapılıyor olduğu da bilinmektedir. Buna rağmen yapılan taramada az sayıda araştırmaya konu olduğu görülmüştür. Bu alanda yapılan ilk araştırma 2009 yılında tamamlanan bir tez çalışmasıdır. Yapılan incelemede dikkat çeken hususlardan biri spor çevirmenliği konusundaki yayınların daha çok futbol çevirmenliğine odaklanmasıdır. Türkiye'de Basketbol gibi farklı spor dallarında da uluslararası temasların yoğun olduğu bilinmektedir. Bundan hareketle Türkiye'de bu alanda yapılan çalışmaların kısıtlı ve sınırlı olduğu ifade edilebilir. Buna göre iç dinamiği farklı olabilecek spor dallarının da odağa alacak araştırmalara ihtiyaç duyulduğu ortaya çıkmaktadır. Öte yandan çalışmaların çoğu sahadaki çeviri uygulamasına odaklanmaktadır. Bu bağlamda çevirmenin rolü ve sorumlulukları ele alınırken, yaşanılan sorunlar da ele alınmaktadır. Çalışmaların biri de özellikle terminoloji konusunu vurgulamaktadır. Buna göre spor çevirmenliği de bir uzmanlık alanı olarak gösterilmektedir. Yapılan çalışmalara bakıldığında, yalnızca bir tanesinin spor çevirmenliğini toplum çevirmenliği içerisinde açıkça konumlandırdığı dikkat çekmektedir. Diğerleri toplum çevirmenliğinden söz etmemektedir. Yapılan araştırmada spor çevirmenliğinin, toplum çevirmenliğinin bir alt alanı olup olamaması konusunda netlik olmadığı gözlemlenmektedir. Buna göre bu konun irdelenmesine ihtiyaç duyulduğu çıarımında bulunulabilir.

\section{g) Toplum çevirmenliği eğitimi ${ }^{27}$}

Toplum çevirmenliği yukarıda afet ve acil durum çevirmenliği, sağllk çevirmenliği, mahkeme çevirmenliği ve spor çevirmenliği gibi alanlara ayrılmıştır. Fakat bu alanların haricinde üst başlık olarak belirli bir alanla sınırlı olmayan, genel anlamda toplum çevirmenliğini ve toplum çevirmenliği eğitimini konu alan kaynaklara da rastlanmıştır. Bu çalışmanın amacı Türkiye'de toplum çevirmenliği ile ilgili yapılan ve yayınlanan bilimsel çalışmalara üst bakış sunmak olduğundan, bu üst bakışın oluşmasında bu türden çalışmalar da önemli rol oynamaktadır. Bu nedenle bu çalışmalar da araştırmaya ayrı bir başlıkla dahil edilmiştir.

Türkiye'de akademik çeviri eğitiminden yirminci yüzyılın sonundan beri söz edilebiliyor. Bu süreçte akademik çeviri eğitiminin amaçları doğrultusunda ve piyasa koşullarındaki değişiklikler ve mesleki gelişmeler de dikkate alınarak müfredatlar ve ders içerikleri zaman zaman yenilenmekte ve güncellenmektedir. Müfredatlar incelendiğinde Toplum Çevirmenliğine ve alanlarına da yer verildiği görülmektedir. Toplum Çevirmenine duyulan ihtiyacın artması ve özellikle meslekleşme sürecinde Toplum Çevirmenliğinin de yeterliliklerinin ${ }^{28}$ yazılması gibi gelişmelerin, çeviri eğitimi veren kurumlarda ders eklenmesine ve mevcut derslerin güncellenmesine neden olduğu söylenebilir. Bu gelişmeler bilimsel çalışmalara da yansımıştır. Son iki yılda Toplum Çevirmenliği eğitimini konu alan çalışmaların yayınlandığı yapılan taramada görülmüştür. Bu çalışma kapsamında yapılan araştırmada çeviri eğitiminde toplum çevirmenliğini ele alan yayınlara da ulaşılmıştır. Türkiye'de eğitim odaklı olarak toplum çevirmenliğini konu alan yayınlar, bütünün \%8’ini oluşturmaktadır.

\footnotetext{
27 Bu alanda yapılan yayınlar: Arslan ve Durdağı (2018), Alimen (2018), Ross (2018)

${ }_{28}$ Toplum Çevirmeni Ulusal Yeterlilik Taslak Metni için bkz.: http://cdn.istanbul.edu.tr/FileHandler2.ashx?f=cevirmenyeterlilikleri---toplum-cevirmeni---yayinlanan-taslak-15.12.2018.pdf
} 
Buna göre Toplum Çevirmenliği Eğitimini ele alan 3 yayına ulaşılmıştır. Bu çalışmaların tamamının 2018 yılında yayınlanmış olması dikkat çekmektedir. Yayınlarda özellikle Türkiye'deki çeviri eğitimi veren kurumlardaki Toplum Çevirmenliği derslerinin plan ve içerikleri konusunda genel bilgiler verilerek durumun betimlendiği görülmektedir. Çalışmalarda Toplum Çevirmenliği derslerinin önemi ifade edilmekte ve ders uygulamaları örnekleri üzerinden öneriler sunulmaktadır. Tarihsel, teorik, teknik bilgilerle birlikte senaryo çalışmalarının rolü ve etkisi de açıklanmaktadır. İncelenen çalışmaların sonuç ve çıkarımları benzer şekilde müfredatların düzenli şekilde güncellenmesi gerektiğinin altını çizerken, terminoloji, alan bilgisi ve sahadaki gerçeklik gibi kuram ve uygulamayı içeren konuları bir arada aktarmanın önemini vurgulamaktadır. Bu bağlamda toplum çevirmenliği uygulamalarının dikkate alınması, yani derslerin sahadaki uygulamalara uygun işlenmesi gerektiği araştırmacılar tarafından açıkça ifade edilmektedir.

\section{h) Toplum çevirmenliği (genel)29}

Toplum Çevirmenliği Genel başlığı altında incelenen çalışmaların yarısından fazlasının tezler olduğu görülmüştür. Tüm çalışmaların yıllarına bakıldığında, özellikle son üç yıldır bu konuya ağırlık verildiği de açıkça ortaya çıkmaktadır. Çalışmalar, genel anlamda toplum çevirmenliğinin durumu, çevirmenlerin rolü ve çalışma ortamları, yasal mevzuatlar gibi konulara değinirken, alandaki ve sahadaki sorunlara çok boyutlu yaklaşımlar sunmuştur. Bu bağlamda mülakat, görüşme, anket gibi saha araştırmalarıyla birlikte betimleyici bir yöntem kullanılarak, mevcut durum ortaya koyulmuştur. Şehirler özelinde, yerel sorunlara odaklanan çalışmaların varlığı da dikkat çekmiştir. Çalışmaların sonuç ve çıkarımları incelendiğinde toplum çevirmenliği konusunda bilinçlendirme gerektiği ve bu kapsamda örneğin işe alımlarda belirli kriterlerin uygulanması gerektiği ifade edilmektedir. Araştırmacılar çevirmenlerin uzmanlaşması gerektiğine işaret ederken, profesyonelliğe vurgu yapmıştır. Özellikle ifade edilen bir başka husus ise çeviri ve çevirmen eğitimlerinin önemi ve eğitimde uygulamaya ağırlık verilmesinin gerekliliğidir.

\section{Sonuç: Türkiye'de toplum çevirmenliği araştırmaları}

Gerçekleştirilen çalışma sonucunda, toplum çevirmenliği konusunda yapılan araştırmaların son yıllarda, hatta son üç yılda çok büyük oranda arttığı görülmüştür. Bu durum, son yıllarda toplum çevirmenliğine duyulan ihtiyacın artmasının ve bununla birlikte oluşan saha-bilim etkileşiminin doğal bir sonucu olarak görülebilir. Araştırmada elde edilen bulgular bibliyografya olarak sunulmuş ve sayısal veriler dikkate alınarak grafikleştirilmiştir. Bununla birlikte toplum çevirmenliği konusunda yapılan çalışmalar üst başlıklar belirlenerek sınıflandırılmış ve incelenmiştir. Son olarak, söz konusu bulgular dikkate alınarak belirlenen üst başlıklara göre tespitler ortaya koyulmuş ve değerlendirme yapılmıştır.

Yapılan araştırmada elde edilen sonuçlar bütünsel olarak değerlendirildiğinde, öncelikle bibliyografya oluşturma amacıyla izlenen yolun sağlıklı verilere ulaşılmasını olanaklı kıldığı ve bu sayede çalışmanın başında ifade edilen soruların yanıtlarını sunduğu ifade edilmelidir. Buna göre çalışmanın araştırma yönteminin, çeşitli amaçlarla yapılabilecek farklı odaklı araştırmalar için uygulanabilir olduğu söylenebilir. Bulgulardan hareketle dikkat çeken bir husus da, toplum çevirmenliği konusunda Türkiye'de yapılan yayınların, toplum çevirmenliğine son yıllarda duyulan ihtiyaca paralel olarak artmış olmasıdır. Öte yandan Türkiye’de meslek standartları çerçevesindeki çalışmalar çeviri alanı için

Bu alanda yapılan yayınlar: Gürçağlar ve Diriker (2004), Başaran (2013), Balkul (2017), Doğan (2017), Şan ve Koçlu (2018), Balkul (2018), Ersoy (2018), Koçlu (2019) 
önemli gelişmelerden biridir. Bu bağlamda yapılan incelemede toplum çevirmenliği yeterlilikleri konusundaki çalışmalara az değinilmiş olması dikkat çeken bir husus olarak ifade edilebilir. Hem bu husus hem de sahada toplum çevirmenlerinin görevlerinin çeşitliliği ve kapsamı düşünüldüğünde, bu alanda ve alt alanlarında bilimsel çalışmalar ve araştırmalar yapılmasının gerekliliği, doğal bir beklenti ve varsayım olarak ortaya çımmaktadır. Buna göre, bu çalışmada gerçekleştirilen araştırmanın bulgularından biri olan bibliyografyanın her daim eksiklik gösterebileceği ve geliştirilmeye ihtiyaç duyacağı da unutulmamalıdır.

\section{Kaynakça}

Acar, E. N. (2017). Halk Sağlğg ile ilgili Metinlerin Çevirisi . İstanbul Üniversitesi, Sosyal Bilimler Enstitüsü, Çeviribilim Anabilim Dalı, Yayımlanmamış Yüksek Lisans Tezi.

Acaroğlu, T. (1961). Bibliografta nedir? Türk Kütüphaneciliği Dergisi, 1O(3-4).

Afette Rehber Çevirmenlik: http://www.ceviridernegi.org/arc.html Erişim Tarihi: 24.11.2019

Aksoy, F. (2007). A comparative study: Translation of legal terminology in English, French and Turkish texts . Hacettepe Üniversitesi, Sosyal Bilimler Enstitüsü, Yayımlanmamış Yüksek Lisans Tezi.

Akyol, F. (2011). A comparative analysis of Newmark's and Vinay \& Darbelnet's methods used in medical translation within the framework of Skopos Theory . Atılım Üniversitesi, Sosyal Bilimler Enstitüsü, Mütercim Tercümanlık Anabilim Dalı, Çeviri Bilim Dalı, Yayımlanmamış Yüksek Lisans Tezi.

Anamur, H. (2013). Başlangıçtan bugüne Fransızcadan Türkçeye yapılmış çeviriler ile: Fransız düşünürler, yazarlar, sanatçllar üzerine Türkçe yayınları içeren bir kaynakça denemesi, Gündoğan Yayınları.

Balkul, H. İ ve Ersoy H. (2016). Çeviribilim Alanındaki Lisansüstü Tezler Üzerine Betimleyici Bir Çalışma. International Journal Of Languages' Education and Teaching. Vol 4(2), s. 151-163.

Bogenç D. E. (2003) Yazın Alanında Fransızca'dan Türkçe’ye Çevrilmiş Eserler Üzerine Bir Bibliyografya Çalışması. Yıldız Teknik Üniversitesi Yayınları

Bulut, A. ve Kahraman, R. (2003) "Voluntary Relief Interpreters as Agents of Intercultural Communication: Ethical Considerations" 1oth Translation Targets Conference 11-13 Eylül 2003 Charles Üniversitesi, Prag.

Bulut, A. ve Şan, F. (2019) "Uluslararası Yardımlaşmada Çeviri Hizmetleri: Afette Rehber Çevirmenlik", 3. Uluslararası Doğal Afetler ve Afet Yönetimi Sempozyumu, (yayınlanmamış sunum) 25-26 Ekim 2019 Van Yüzüncü Yıl Üniversitesi, Van.

Can, M.Z ve Balkul, H.İ ve Gümüş A.F. ve Çalık O. (2018) Türkiye'deki Akademik Çeviri Camiasının Makale Düzeyindeki Çalışmalarının Yayın Mecrasının Araştırılması Ve Değerlendirilmesi. Filolojide Güncel Araştırmalar Çalışması, s. 150-167, Gece Kitaplığı Yayınları

Çevirmen Meslek Standardı: https://www.myk.gov.tr/images/articles/editor/2013/300113/CEVIRMEN_Seviye_6_UMS.pd f Erişim Tarihi 12.11.2019

Demirakın, N. (1999). Methods used in the translation of legal documents . Hacettepe Üniversitesi, Sosyal Bilimler Enstitüsü, Yayımlanmamış Yüksek Lisans Tezi.

Doğan, A. (1995). Simultane Tip Çevirisi Eğitiminde Bellek Destekleyici Anahtar Sözcük Yönteminin Etkililik Derecesi. Hacettepe Üniversitesi, Sosyal Bilimler Enstitüsü, Eğitim Programları ve Öğretim Bilim Dalı, Yayımlanmamış Doktora Tezi.

Doğan, A. (2004). Mahkeme Çevirmenliği. Hacettepe Üniversitesi Uygulamal Çeviribilim Dergisi (14), 1-24. 
Doğan, A. (2010a). "Afetlerde Çevirmenlik Hizmetleri” HAMER Acil ve Afet Durumlarında Sağllk Sağllk Yönetimi Semineri (yayınlanmamış sunum), 10 Haziran 2010. Hacettepe Üniversitesi, Ankara.

Doğan, A. (2010b). “Türkiye'de Acil Durum ve Afet Çevirmenliği: Geçmişten Bugüne”, Community Interpreting in Turkey, (yayınlanmamış sunum) 22-23 Kasım 2010, Boğaziçi Üniversitesi, İstanbul.

Doğan, A. (2015). Mahkeme Çevirmenliği Alanı ve Eğitimi . Genç Tercümanlar Çalıştayı . içinde Ankara

Duraner, J. E. (2015). Mapping network in legal translation market in Turkey: Analysis of actors from sociological perspective. Dokuz Eylül Üniversitesi, Sosyal Bilimler Enstitüsü, Mütercim Tercümanlık Anabilim Dalı, Yayımlanmamış Yüksek Lisans Tezi.

Filatova, Ş. (2017). Becoming a medical translator: Who are the experts? . İstanbul 29 Mayls Üniversitesi, Sosyal Bilimler Enstitüsü, Çeviribilim ABD, Yayımlanmamış Yüksek Lisans Tezi.

Gümüss, V. Y. (2006). The importance of extralinguistic factors in the translation of legal texts . Hacettepe Üniversitesi, Sosyal Bilimler Enstitüsü, Yayımlanmamış Yüksek Lisans Tezi.

İnsan Hakları Evrensel Beyannamenin (Türkçe): http://www.unicef.org.tr/files/bilgimerkezi/doc/insan\%2ohaklari\%20evrensel\%2obeyannemes i.pdf Erişim Tarihi: 05.11.2019

Kaçan, A. (2017). Level of Equivalence In The Translation of British and Turkish Legal Texts . Atılım Üniversitesi, Sosyal Bilimler Enstitüsü, Çeviribilim Anabilim Dalı, Çeviri Bilim Dalı, Yayımlanmamış Yüksek Lisans Tezi.

Kader, B. (2011) İtalyancadan Türkçeye Çevrilen Eserler Bibliyografyası 1839-2011, Beta Yayınları

Kahraman, R. (2003). Afette Rehber Çevirmenlik. İstanbul Üniversitesi, Sosyal Bilimler Enstitüsü, Çeviri Anabilim Dalı. Yayınlanmamış Yüksek Lisans Tezi.

Kahraman, R. (2010). Göç ve Çeviri: İltica Başvurularında Sözlü Çeviri Uygulamaları ve Toplum Çevirmeninin Rolü. İstanbul Üniversitesi, Sosyal Bilimler Enstitüsü, Çeviribilim Anabilim Dalı. Yayınlanmamış Doktora Tezi .

Kızılay Toplum Merkezleri -Toplum Çevirmeni Eğitim Programı: https://www.academia.edu/37799893/K\%C4\%B1z\%C4\%B1lay_Toplum_\%C3\%87evirmenli\%C 4\%9Fi_E\%C4\%9Fitim_Projesi_Program\%C4\%B1_Gaziantep_3_4_Kas\%C4\%B1m_2018 Erişim Tarihi: 06.12.2019

Kocabiylk, B. (2006). The Methods used in Syntactic and Lexical Levels in the Translation of Documents of the European Union. Hacettepe Üniversitesi, Sosyal Bilimler Enstitüsü, Yayımlanmamış Yüksek Lisans Tezi.

Koçlu, S. (2019). Göç ve Çeviri İlişkisi Bağlamında Toplum Çevirmenliğine Üst Bakış: Sakarya Örneği. Sakarya Üniversitesi, Sosyal Bilimler Enstitüsü, Çeviribilim ABD, Yayımlanmamış Yüksek Lisans Tezi.

Kurultay T. ve Bulut A. (2012). Toplum Çevirmenliğine Yeniden Bakışta Afette Rehber Çevirmenlik (ARÇ). İstanbul Üniversitesi Çeviribilim Dergisi(6), 75-102.

Mikkelson, H. (1996). The Professionalization of Community Interpreting, Murial M. JeromeO'Keffe içinde, Global Vision, Proceeding of the 37th Annual Conference of the American Translators Association, American Translators Association, 77-89.

Mikkelson, H. (2014). Evolution of Public Service Interpreting Training in the U.S. International Journal(1), 9-22.

Milli Kütüphane: http://www.mkutup.gov.tr/tr/Sayfalar/Hizmetlerimiz/Yayinlarimiz.aspx Erişim Tarihi: 02.12.2019 
Mutlu, S. (2012). Hukuk çevirilerinde ortaya çıkan çeviri sorunlarını boşanma davaları örneğinde incelenmesi. . Sakarya Üniversitesi, Sosyal Bilimler Enstitüsü, Çeviribilim Anabilim Dalı, Çeviri Bilim Dalı, Yayımlanmamış Yüksek Lisans Tezi. .

Odacioğlu, M. (2011). The translation of medical texts: A case study on Arthur C. Guyton and John E. Hall's textbook of medical physiology. Hacettepe Üniversites, Sosyal Bilimler Enstitüsü, Çeviribilim Anabilim Dalı, Yayımlanmamış Yüksek Lisans Tezi. .

Orhan, E. (2017). Methods used in the Turkish Translation of Legal Terminology in the Judgments of the European Court of Human Rights . Hacettepe Üniversitesi, Sosyal Bilimler Enstitüsü, Mütercim Tercümanlık ABD, Yayımlanmamış Yüksek Lisans Tezi.

Özdoğan, M. (2009). Contribution of translation activity on the development of medicine through historical perspective from Hippocratic Era to the 15th century . Hacettepe Üniversitesi, Sosyal Bilimler Enstitüsü, Mütercim Tercümanlık (İngilizce) BD, Yayımlanmamış Yüksek Lisans Tezi. .

Özkaya, E. (2015). Konferans Çevirmenliğinde Normlar Işı̆̆ında Tarafsızlık Kavramı. İstanbul Üniversitesi, Sosyal Bilimler Enstitüsü, Çeviribilim Anabilim Dalı, Çeviri Bilim Dalı, Yayımlanmamış Doktora Tezi.

Özkeser, O. (2004). Plazma nitrürlemede kullamılmak üzere alçaltıcı tip çevirici tasarımı ve gerçekleştirilmesi . İstanbul Teknik Üniversitesi, Fen Bilimleri Enstitüsü, Elektrik Mühendisliği Anabilim Dalı, Yayımlanmamış Yüksek Lisans Tezi.

Parlak, B. (2011). Bir Çeviri Eserler Bibliyografyası Işığında Türkçede İtalyan Kültürü, Beta Yayıncılık.

Perez I. ve C. W. (2004 ). Wilson Interpreter-mediated police interviews- Working as a professional team. B. E.-L. Cecilia Wadensjö içinde, The Critical Link 4 (s. 79-93). John Benjamins Publishing.

Pöchhacker, F. (1999). Getting Organized: The Evolution of Community Interpreting. Interpreting (Cilt 1, s. 125-140). içinde John Benjamins Publishing Company.

Pöllabauer, S. (2004). Interpreting in asylum hearings: Issues of saving face . B. E.-L. Cecilia Wadensjö içinde, The Critical Link 4 (s. 39-52). John Benjamins Publishing Company.

Ross, J. M. (2015). Sağlık Alanında Amatör Sözlü Çevirmenlik . Genç Tercümanlar Çahıştayı . içinde Ankara .

Rillof P. ve L. B. (2015). Getting organized to beat Babel in multilingual service encounters: The European Network for Public Service Interpreting and Translation (ENPSIT). The International Journal for Translation \& Interpreting Research, 3(7), 186-197.

Sağlık Çevirmenliği alanında örnek uygulama: https://www.gesundheitnordhessen.de/index.php?parent=1152 Erişim Tarihi: 05.12.2019

Saka, H. (2005). Effect of phraseological field knowledge in the course and on the output of simultaneous medical interpreting. Hacettepe Üniversitesi, Sosyal Bilimler Enstitüsü, Yayımlanmamış Yüksek Lisans Tezi.

Sakarya Adliyesi 2019 Bilirkişi Listesi: http://www.sakarya.adalet.gov.tr/duyurular/2019tercumankesin.pdf Erişim Tarihi: 01.12.2019

Slapp, M. A. (2004). Community Interpreting in Deutschland: Gegemwaertige Situation und Perspektivem für die Zukunft. Münih: Martin Meidenbauer Verlagsbuchhandlung.

Şan F. ve Koçlu S. (2018). Sakarya'daki Mültecilerin İletişim Sorunlarının Belirlenmesi ve Toplum Çevirmenliğine Olan İhtiyaç. International Journal of Language Academy, 4(6), 1-16.

Şan F. ve Koçlu S. (2019). Toplum Çevirmenliği Odağında Türkiye'de Yapılan Lisansüstü Tezlere Betimleyici Bir Üst Bakış. Can Z. ve Şan F. içinde, Çeviribilimde Güncel Çalışmalar I., 232-255.

Toplum Çevirmeni Ulusal Yeterlilik Taslak Metni: http://cdn.istanbul.edu.tr/FileHandler2.ashx?f=cevirmen-yeterlilikleri---toplum-cevirmeni--yayinlanan-taslak-15.12.2018.pdf Erişim Tarihi: 12.11.2019 
Uyanık, G. B. (2015). Spor Çevirmenliğinde Durumların ve Görevlerin Tanımlanması . İstanbul Üniversitesi, Sosyal Bilimler Enstitüsü, Çeviribilim ABD, Yayımlanmamış Yüksek Lisans Tezi.

Yeşilkaya, Z. (2017). Çeviri uygulamalarında koşut metinlerin işlevi: Hukuk metinleri temelli bir inceleme. İstanbul Üniversitesi, Sosyal Bilimler Enstitüsü, Çeviribilim Anabilim Dalı, Yayımlanmamış Yüksek Lisans Tezi.

YÖK Tez Merkezi: https://tez.yok.gov.tr/UlusalTezMerkezi/ Erişim Tarihi: 05.12.2019 